\title{
A regional approach to the study of industrial diversity in Argentina (1996-2012) ${ }^{1}$
}

\author{
Andrea Belmartino and Carla Daniela Calá
}

\begin{abstract}
The aim of this paper is to quantify the productive diversity of the manufacturing industry in the provinces of Argentina, to analyse trends in productive diversity between 1996 and 2012, and to identify the main related economic factors. A diversity index is calculated based on official data on total registered wage employment from the Dynamic Employment Analysis Database (BADE). An analysis is then performed of trends in diversity in the different provinces over the period. Lastly, an econometric panel data model is estimated to identify the main related economic factors. The industrial diversity of the provinces is negatively associated with withdrawal of firms and positively associated with level of development, region size, higher levels of urbanization and greater territorial capabilities. The results of this study can be used to design policies to promote regional diversity.
\end{abstract}

\section{Keywords}

Industry, industrial enterprises, manufacturing enterprises, manufactures, econometric models, industrial statistics, Argentina

\section{JEL classification}

$$
\text { L60, R11 }
$$

\section{Authors}

Andrea Belmartino is a full-time graduate assistant at the Economic Research Centre of the Faculty of Economics and Social Sciences of the National University of Mar del Plata, Argentina. Email: belmartino@mdp.edu.ar.

Daniela Calá is a full-time adjunct professor at the Economic Research Centre of the Faculty of Economics and Social Sciences of the National University of Mar del Plata, Argentina. Email: dacala@mdp.edu.ar.

The authors would like to thank the Employment and Business Dynamics Observatory (Ministry of Labour, Employment and Social Security) for providing access to the data, and Javier Alejo of the National University of La Plata (UNLP), and the participants in the twenty-first Annual Meeting of the MERCOSUR SME Network (Tandil, 2016) and the sixth Annual Meeting of the Argentine Political Economics Association (Tucumán, 2016) for their valuable comments on previous versions of this paper. 


\section{Introduction}

Productive diversity is key to the design of countries' development strategies. In particular, the variety of goods produced and exported is directly related to economic development, in its early stages (Imbs and Wacziarg, 2003; Klinger and Lederman, 2004; Hidalgo and Hausmann, 2010). Diversity in productive structures generates additional benefits, such as promoting innovation and knowledge transmission (Duranton and Puga, 2000; Frenken, Van Oort and Verburg, 2007), reducing vulnerability to external shocks (Ghosh and Ostry, 1994; Kosacoff and Ramos, 1999; Haddad, Lim and Saborowski, 2010), incentivizing the entry of new firms (Guesnier, 1994; Reynolds, Storey and Westhead, 1994) and increasing investment opportunities (Al-Marhubi, 2000; Herzer and Nowak-Lehnmann, 2006; Hesse, 2009).

These empirical findings give productive diversity a central role in the design of industrial policies on local development. It is therefore important to know how diverse regional production structures are, how their diversity has changed over time, and what the related economic factors are. This article offers a regional view of this phenomenon based on a twofold analysis: firstly, it describes the trend in productive diversity of industry in the Argentine provinces between 1996 and 2012; and secondly, it examines the relationship between industrial diversity and some characteristics of the regions, such as their degree of development, level of urbanization, presence of resources and capabilities, and variables of business dynamics. Based on this, the aim is to generate meaningful information that can be used in the design of industrial development policies at the regional level.

The results obtained enable a deeper understanding of productive diversity, which the Economic Commission for Latin America and the Caribbean (ECLAC) has called a key mechanism for developing new technological capabilities in the framework of implementation of selective industrial policies (Lavarello and Sarabia, 2015). In this regard, and in keeping with the 2030 Agenda for Sustainable Development, ECLAC affirmed in 2017 the need to move towards more knowledge-intensive sectors that facilitate productive diversification, to generate new opportunities for social integration and inclusion. ${ }^{2}$

In Argentina, this issue has also been highlighted in the lines of action of the 2020 Strategic Plan for Industry (Ministry of Industry, 2011), which underscore the importance of actions that promote a more diversified production in order to achieve sustainable growth with equity (Porta, 2016). However, this growing interest contrasts with the limited number of academic contributions that address the phenomenon empirically, from a regional perspective. The papers that study productive diversity in Argentina mainly focus on analysing exports at the country level (Bebczuk and Berrettoni, 2006), or the distribution of employment in certain geographical areas (Fritzsche and Vio, 2000; Rojo Brizuela and Rotondo, 2006; Mazorra and Beccaria, 2007).

The article is structured as follows: first, it summarizes the main theoretical and empirical works that help to identify and understand the economic factors linked to regional productive diversity. Next, the data source, diversity index and estimation method are described. The results are then outlined, followed by some reflections and possible future lines of research.

\section{Theoretical framework}

This work falls within the field of regional science, meaning the set of studies that encompass the territorial dimension and its heterogeneities in economic analysis (Moncayo Jiménez, 2001). Although this field of science has provided theoretical models that allow for rigorous study of certain issues such as regional growth or the territorial concentration of economic activity (Capello, 2006), there are not

\footnotetext{
2 Bielschowsky, Izam and Mulder (2011) summarize the evolution of ECLAC thinking on productive diversification and international integration from 1950 to the present.
} 
yet any models that adequately describe the phenomenon of regional productive diversity. That is why empirical studies on the subject (see section III) often use ad hoc econometric specifications, incorporating elements from different theoretical frameworks. In particular, this paper draws on arguments from two approaches: (i) new economic geography (Krugman, 1991, 1995, 1998 and 1999); and (ii) resources and capabilities (Penrose, 1959; Teece, 1980; Montgomery, 1994).

\section{New economic geography}

This approach consists of a set of general equilibrium models in a structure of imperfect competition that take into account the existence of increasing returns to scale, transport costs and the possibility of territorial movement of production factors and consumers (Krugman, 1991; Fujita and Krugman, 2004). While these models generate a wide variety of results depending on specific assumptions, new economic geography highlights a number of elements that may explain productive diversity in large urban areas (Bishop and Gripaios, 2007).

Krugman (1998) suggests that there are two opposing forces: centripetal forces (which concentrate economic activity geographically and centrifugal forces (which dissipate it). Centripetal forces originate from circular causation: workers find better quality infrastructure, higher real wages and a greater variety of goods in large urban areas, while firms select locations in large markets to benefit from internal and external economies of scale. Similarly, within the concept of external economies there is often differentiation between the forces of localization and those of urbanization. The forces of localization are the benefits derived from the proximity of firms in the same industrial sector (specialized labour market, suppliers and technological spillovers), while the forces of urbanization are independent of the industrial sector (public, financial and commercial services, knowledge transfer) (Hoover, Jr., 1936). Evidence indicates that localization economies are particularly important for traditional manufacturing, while urbanization economies have a greater impact on services and high-tech manufacturing (Henderson, Kuncoro and Turner, 1995). In this regard, a more urbanized environment that facilitates knowledge transfers and innovation, will also be more conducive to productive diversity (Glaeser and others, 1992; McCann and Van Oort, 2009).

\section{Regional resources and capabilities}

The resource-based view arises from Penrose's (1959) contribution to the analysis of firms. Under this approach, firms are analysed on the basis of their "inherited" resources (Teece, 1980; Montgomery, 1994). This theory can also be applied to regions, which can be defined by their resource endowments, either tangible (such as infrastructure) or intangible (such as the human capital of their workers or the quality of their institutions) (Lawson, 1999; Boschma, 2004; Neffke and others, 2014; Boschma and Capone, 2015). Since resource endowments and capabilities determine which production activities can be carried out by firms in a region, they must be included as a factor that is associated with the degree of regional productive diversity and its evolution.

In this regard, the more modern approach proposed by Hidalgo and others (2007) analyses the network of relatedness between products and industries, originating from input-output links, technological sophistication and the use of similar capabilities or infrastructure. Under this approach, the development of greater capabilities, in a broad sense (such as productive, organizational and institutional capabilities), makes it possible to expand the product range and even produce more complex goods. This is why countries tend to diversify into products that are comparable to those they already export, i.e. goods that require similar capabilities. At the regional level, diversification also tends to occur in industries that are related to existing activities (Neffke, Henning and Boschma, 2011). The process is affected by the local industrial history, the territory's accumulated capabilities and the path dependence of the region (Martin and Sunley, 2006; Neffke and others, 2014). 


\section{Empirical background}

The subject of productive diversity has been studied in the context of multiple disciplines and paradigms (Ramanujan and Varadarajan, 1989). In this regard, there are at least three dimensions of analysis: firm, region and country. In particular, work at the regional level has grown considerably in recent years (Frenken and others, 2004), especially in developed countries. ${ }^{3}$

Empirical evidence indicates that there is a positive correlation between a region's productive diversity and its size (Duranton and Puga, 2000; Monastiriotis, 2000; Beckstead and Brown, 2003; Bishop and Gripaios, 2007) and level of urbanization (Dewhurst and McCann, 2002; Bishop and Gripaios, 2007). In other words, as is to be expected in accordance with the elements indicated in new economic geography, the largest and most densely populated urban areas are also the most diverse.

Moreover, empirical studies that adopt a resources- and capabilities-based approach are faced with the difficulty of proper identification. Existing research quantifies regional capabilities by using proxy variables such as research and development (R\&D) intensity (Aw and Batra, 1998; Parteka and Tamberi, 2011); the ratio of managers or technical personnel to total industry employment (Baldwin and others, 2000); number of employees in science- and technology-based industries (Baldwin and others, 2000; Bishop and Gripaios, 2007); or the educational level of the population (Parteka and Tamberi, 2011).

Some empirical studies link the degree of diversity of a region or country with its level of development, measured in terms of per capita gross domestic product (GDP). In this regard, De Benedictis, Gallegati and Tamberi (2009), and Parteka and Tamberi (2011) conclude that regions with lower per capita GDPs have a lower degree of relative production heterogeneity. In this regard, Imbs and Wacziarg (2003) show that the relationship between per capita GDP and diversity at the country level is non-linear, meaning that there is a positive correlation between growth and a more diverse production and export structure until countries reach certain income levels, at which point the relationship reverses and countries begin to specialize again.

A final group of papers draws on elements related to business dynamics to explain changes in regional productive diversity. These studies affirm that an increase in regional diversity can be evidenced by:

- the creation of new firms in existing industries but with a lower relative share of regional employment ("non-traditional" sectors), or growth of existing firms in those industries (Neffke, Henning and Boschma, 2011);

- the exit of firms or a contraction in employment in industries that account for a larger proportion of employed persons in the region ("traditional" sectors);

- the entry of new production industries (Kamien and Schwartz, 1975).

In short, a positive correlation is expected between regional productive diversity and the degree of regional development, the size of the region, higher levels of urbanization and the level of capabilities in the territory. Likewise, productive diversity is expected to be associated with certain variables of business dynamics (entry and exit of firms), although it is not possible to establish the direction of the relationship, a priori.

\footnotetext{
3 For example, Beckstead and Brown (2003) in Canada; Rodgers (1957); Monastiriotis (2000) and Essletzbichler and Rigby (2007) in the United States; Boschma, Minondo and Navarro (2013) in Spain; Bishop and Gripaios (2007) in the United Kingdom; and Boschma and lammarino (2007) and Marra, Carlei and Paglialunga (2011) in Italy. The number of empirical studies in developing countries is small, owing to the lower quality and availability of data (Nachum, 2004; Hammouda and others, 2006).
} 


\section{Methodology}

\section{Data source}

The main source of information is the Dynamic Employment Analysis Database (BADE), compiled by the Employment and Business Dynamics Observatory (OEDE), part of the Ministry of Labour, Employment and Social Security of Argentina. The unit of analysis is firms, identified by Unique Tax Identification Codes (CUIT). The database is constructed from firms' filings with the Integrated Retirement and Pension System and therefore contains data on total registered wage employment in the private sector in Argentina (Castillo and others, 2004). Industrial employment data have been used, disaggregated at the two-digit level of the International Standard Industrial Classification of All Economic Activities (ISIC), Rev. 3.1, (see annex 1) and at the regional level in the 24 administrative areas that make up the territory of Argentina (23 provinces and the city of Buenos Aires).

To characterize the provinces, various data sources were also consulted, namely the National Population and Housing Census, the statistical yearbooks of the National Institute of Statistics and Censuses (INDEC), provincial statistics departments and data published by the Ministry of Industry and the Ministry of Science and Technology, as well as those on BADE.

\section{Productive diversity index}

The use of regional diversity indices allows a great volume of information to be easily summarized and interpreted. As is customary in the specialized literature (Aw and Batra, 1998; Duranton and Puga, 2000; Hammouda and others, 2006; Klinger and Lederman, 2004; Parteka and Tamberi (2011); Cadot, Carrère and Strauss-Kahn, 2011), this paper uses the inverse of the Herfindahl-Hirschman index $(\mathrm{HHI})$ as a measure of diversity, constructed from data on regional registered wage employment in manufacturing. ${ }^{4} \mathrm{HHI}$ is defined as the sum of each sector's share of regional employment, squared (Duranton and Puga, 2000). The inverse of the index is as follows:

$$
P D_{i}=1 / H H I=1 / \sum_{j=1}^{J}\left(\frac{E_{i}^{j}}{E_{i}}\right)^{2}
$$

where $E_{i}^{j}$ is the number of employees in sector $j$ in region $i$ and $E_{i}$ is the total number of the industry's employees in the region.

\section{Model}

To examine the relationship between the productive diversity in manufacturing and the associated economic factors, an econometric panel data model is estimated. One of the main advantages of using this type of model is that it controls heterogeneity, both between individuals and over time (Baltagi, 2008). It is thus possible to control some characteristics of the provinces (whether observable or not) that do not change to a great extent over the period (such as natural resource endowments or institutional arrangements).

\footnotetext{
4 Alternatively, the index can be calculated from product or value added data, but such information is not available at the regional level in Argentina.
} 
The model specification is presented in equation (2), which includes fixed effects by province and dummy variables by year to capture time effects $\left(\theta_{t}\right)$. The dependent variable $\left(P D_{i t}\right)$ is the productive diversity index defined in equation (1).

$$
\begin{gathered}
P D_{i t}=\beta_{0}+\beta_{1} p c G G P_{i t}+\beta_{2} \text { Density }_{i t}+\beta_{3} R \& D_{-} \text {expend }_{i t}+\beta_{4} \text { Sh_expo }_{i t} \\
+\beta_{5} \text { Entry }_{i t}-\beta_{6} \text { Exit }_{i t}+\beta_{t} \theta_{t}+\varepsilon_{i t}
\end{gathered}
$$

The subindices refer to region $i$ and time $t$. Table 1 lists the explanatory variables of the model, their expected sign and the data source. This information is summarised in table 1 and the correlation matrix is shown in annex 2.

Table 1

Argentina: factors associated with regional productive diversity: definition, data source,

\begin{tabular}{|c|c|c|c|c|c|c|c|c|}
\hline \multirow{2}{*}{ Associated factor } & \multirow{2}{*}{ Variable } & & \multirow{2}{*}{$\begin{array}{l}\text { Expected } \\
\text { sign }\end{array}$} & \multirow{2}{*}{$\begin{array}{l}\text { Data } \\
\text { source }\end{array}$} & \multicolumn{4}{|c|}{ Descriptive statistics } \\
\hline & & & & & Mean & Deviation & Minimum & Maximum \\
\hline Development & $\begin{array}{l}\text { Per capita gross geographic } \\
\text { product (in millions of pesos } \\
\text { at constant } 1993 \text { values) }\end{array}$ & $p c G G P$ & + & $\begin{array}{l}\text { CEP } \\
\text { PS }\end{array}$ & 0.007 & 0.005 & 0.002 & 0.034 \\
\hline Level of urbanization & Population density & Density & + & INDEC & 0.581 & 1.843 & 0.015 & 11.888 \\
\hline \multirow[t]{2}{*}{$\begin{array}{l}\text { Resources } \\
\text { and capabilities }\end{array}$} & $\begin{array}{l}\text { Public expenditure on R\&D } \\
\text { (current values - log) }\end{array}$ & $R \& D \_$expend & + & INDEC & 10.535 & 1.504 & 6.968 & 15.481 \\
\hline & Share of exports & Sh_expo & + & INDEC & 3.978 & 8.010 & 0.036 & 39.447 \\
\hline \multirow[t]{2}{*}{ Business dynamics } & $\begin{array}{l}\text { Entry of industrial firms } \\
\text { (number of firms) }\end{array}$ & Entry & $+/-$ & OEDE & 199.394 & 415.620 & 2.000 & 2946.00 \\
\hline & $\begin{array}{l}\text { Exit of industrial firms } \\
\text { (number of firms) }\end{array}$ & Exit & $+/-$ & OEDE & 180.666 & 392.213 & 4.000 & 2540.00 \\
\hline
\end{tabular}
expected sign and descriptive statistics

Source: Prepared by the authors.

Note: CEP: Production Research Centre; PS: provincial statistics departments; INDEC: National Institute of Statistics and Censuses; OEDE: Employment and Business Dynamics Observatory.

Firstly, a region's degree of development, estimated on the basis of the per capita gross geographic product $(p c G G P$ ) is expected to have a positive correlation with its productivediversity (De Benedictis, Gallegati and Tamberi, 2009; Parteka and Tamberi, 2011). Provincial gross geographic product (GGP) data have been used, as published by the Production Research Centre (Ministry of Industry) and by the provincial statistics departments. The data have been deflated using the implicit price index (IPI) for Argentina and the Buenos Aires province IPI (in the robustness analysis), since there are no constant price pcGGP data (or price indices) for all provinces over the period analysed.

In addition, in order to evaluate the relationship between the degree of diversity and the level of urbanization of each region, a density variable is included, measured as the quotient between the population of each province and its area in square kilometres. As a measure of regional capabilities, public expenditure on research and development ( $R \& D$ expend) is included, as is each province's percentage share of the country's total exports (Sh_expo). According to Castellacci (2007), Filipescu and others (2013), and Artopoulos, Friel and Hallak (2013), entry into the external market can be understood as a result of development of productive, organizational or institutional capabilities. Thus, a region that is oriented towards the international market requires greater learning and sophistication in its exporting firms and local suppliers, to adjust to the characteristics of the new demand. Stimulation of external demand can also encourage development of new products and processes, boosting diversity through "demand-pull" (Schmookler, 1966; Crépon, Duguet and Mairesse, 1998). 
Lastly, it is not possible to establish a priori the direction of the correlation between the degree of diversity and the variables of business dynamics (number of industrial firms that are established or closed during the year). There will be a positive correlation between diversity and the entry of firms when they enter less traditional sectors. It will be negative if the entry is into traditional activities, i.e. those that account for a high share of regional employment (Dumais, Ellison and Glaeser, 2002; Noseleit, 2010). Conversely, there is a negative (positive) correlation between the exit of firms and diversity if closures occur in less (more) traditional sectors in each region (Duranton and Puga, 2000; Noseleit, 2010). The data on business dynamics are from BADE, published by OEDE.

\section{The manufacturing industry in Argentina}

The manufacturing industry in Argentina accounted for $67 \%$ of exports (33\% agricultural and $34 \%$ industrial), $22.5 \%$ of GDP and $20 \%$ of employment in 2012. Each region has a different industrial profile, depending on the relative importance of industry in each province and the type of specialization (see table 2).

Table 2

Argentina: industrial sector's share of total provincial employment

\begin{tabular}{|c|c|c|c|c|c|c|}
\hline \multirow{2}{*}{ Provincial groups } & \multirow{2}{*}{ Province } & \multicolumn{2}{|c|}{$\begin{array}{c}\text { Percentage of } \\
\text { industrial employment }\end{array}$} & \multicolumn{3}{|c|}{$\begin{array}{l}\text { Major manufacturing industries } \\
\left.\text { (ISIC division }^{\mathrm{a}}-2012\right)^{\mathrm{b}}\end{array}$} \\
\hline & & 1996 & 2012 & 1 & 2 & 3 \\
\hline \multirow[t]{4}{*}{ 1. Production and consumption hub } & City of Buenos Aires & 18.8 & 13.7 & 15 & 26 & 22 \\
\hline & Buenos Aires & 33.6 & 26.5 & 15 & 24 & 25 \\
\hline & Santa Fe & 31.0 & 26.1 & 15 & 29 & 28 \\
\hline & Córdoba & 26.7 & 21.1 & 15 & 34 & 29 \\
\hline \multirow[t]{5}{*}{ 2. Promotes industry } & San Luis & 51.9 & 34.7 & 15 & 17 & 25 \\
\hline & San Juan & 26.6 & 17.3 & 15 & 26 & 24 \\
\hline & Catamarca & 27.1 & 21.5 & 15 & 17 & 18 \\
\hline & La Rioja & 44.1 & 33.9 & 15 & 17 & 19 \\
\hline & Tierra del Fuego & 28.4 & 36.9 & 32 & 34 & 25 \\
\hline \multirow[t]{8}{*}{ 3. Agro-industrial complex } & Tucumán & 25.6 & 16.0 & 15 & 17 & 28 \\
\hline & La Pampa & 13.9 & 11.5 & 15 & 17 & 26 \\
\hline & Entre Ríos & 21.1 & 18.8 & 15 & 20 & 28 \\
\hline & Salta & 16.0 & 14.2 & 15 & 16 & 24 \\
\hline & Río Negro & 10.6 & 8.9 & 15 & 24 & 26 \\
\hline & Mendoza & 25.3 & 19.3 & 15 & 26 & 29 \\
\hline & Jujuy & 29.8 & 22.0 & 15 & 27 & 16 \\
\hline & Santiago del Estero & 15.4 & 10.7 & 15 & 17 & 26 \\
\hline \multirow[t]{3}{*}{ 4. Oil and fishing complexes } & Neuquén & 11.3 & 7.9 & 15 & 28 & 29 \\
\hline & Chubut & 17.3 & 11.6 & 15 & 17 & 27 \\
\hline & Santa Cruz & 6.5 & 5.4 & 15 & 29 & 28 \\
\hline \multirow[t]{4}{*}{ 5. Forestry and textile complexes } & Chaco & 16.9 & 12.0 & 15 & 17 & 26 \\
\hline & Formosa & 11.6 & 7.3 & 15 & 24 & 36 \\
\hline & Corrientes & 18.4 & 15.1 & 15 & 20 & 17 \\
\hline & Misiones & 30.5 & 21.2 & 15 & 20 & 21 \\
\hline
\end{tabular}

Source: Prepared by the authors, on the basis of the Dynamic Employment Analysis Database (BADE).

a ISIC, Rev. 3.1.

b In terms of employment. 
In the provinces that are the country's main production and consumption hubs (Buenos Aires, Santa Fe and Córdoba), industry is relatively more important in terms of employment: the proportion of industrial employment in these administrative areas is higher than the national average (20\%). The city of Buenos Aires specializes in services, mainly owing to the diseconomies of the urban area for industrial production. In these administrative areas, as in the rest of the country's provinces (except Chaco and Tierra del Fuego), the main sector is the manufacture of food products and beverages (division 15). It is followed in order of importance by industries linked to the population (such as publishing and printing, division 22 or to the agricultural sector (machinery and equipment, division 29).

Another group of provinces with industrial activity levels higher than the national average comprises the regions that benefit from frameworks to promote industrial activity (Tierra del Fuego, San Luis, La Rioja and Catamarca). ${ }^{5}$ In these provinces, the activities with the greatest relative weight are those fostered by promotion policies (such as the manufacture of radio, television and communication equipment and apparatus (division 32) in Tierra del Fuego, or the manufacture of textiles (division 17)).

A third group of provinces has a markedly agro-industrial profile (Tucumán, La Pampa, Entre Ríos, Salta, Río Negro, Mendoza, Jujuy and Santiago del Estero). Food and beverage manufacturing accounts for more than 50\% of registered industrial employment. Neuquén, Chubut and Santa Cruz are characterized by activities related to oil and fishing complexes. Lastly, the fifth group comprises provinces where industries (sawmilling, group 201; furniture, division 36; and textiles, division 17) are linked to the natural resources present in the region (Chaco, Corrientes, Formosa and Misiones).

\section{Results}

\section{Productive diversity of industry at the national and regional levels (1996-2012)}

The productive diversity of Argentine industry is closely related to the macroeconomic fluctuations of the past 20 years, which affected the economy in general and the manufacturing industry in particular. Figure 1 shows that industrial diversity is a clearly procyclical phenomenon, meaning that it follows a similar pattern to GDP (measured on the right scale). The diversity indicator declined continuously from 1998 onward, bottoming out in 2002 following the emergence of the political, economic and social crisis in Argentina in late 2001. During the period of economic recovery that began in 2003, industrial diversity increased steadily, even surpassing pre-crisis values, peaking in 2008. From that year onward, industrial diversity declined again, mirroring the international financial crisis and the gradual appreciation of the exchange rate, and failed to recover in subsequent periods. The positive correlation between the industrial diversity indicator and gross domestic product at market prices (GDPmp) is statistically significant, with similar results for the GDPmp growth rate (see table 3). ${ }^{6}$

However, within Argentina, is diversity also a procyclical phenomenon in all the regions? Are all the provinces equally diverse? What economic factors can be associated with a greater or lesser degree of industrial productive diversity?

\footnotetext{
5 The provinces with frameworks to promote industrial activity are La Rioja (Law No. 22.021/79), San Luis and Catamarca (Law No. 22.702/82) and San Juan (Law No. 22.973). Tierra del Fuego is considered a Special Customs Area (Law No. 19.640/72).

6 From 2007 onward, the markedly positive correlation between the two variables was interrupted. This may be because of an overestimation of GDP in real terms as a result of action in 2007 by the official statistics body (INDEC).
} 
Figure 1

Argentina: industrial diversity (1/HHI) and gross domestic product at market prices (GDPmp), 1996-2012

(Millions of pesos at constant 1993 prices)

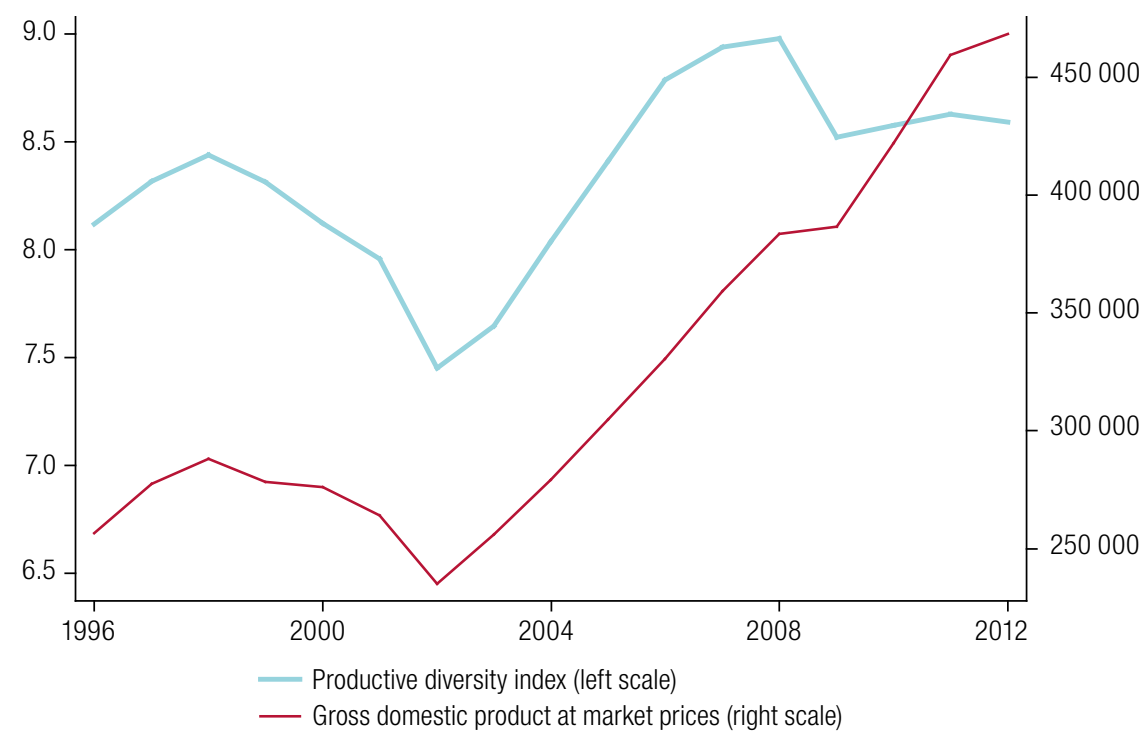

Source: Prepared by the authors, on the basis of the National Institute of Statistics and Censuses (INDEC) and the Dynamic Employment Analysis Database (BADE).

Note: $\quad H H I$ : Herfindahl-Hirschman index.

Table 3

Argentina: correlation between gross domestic product at market prices (GDPmp) and the diversity index

\begin{tabular}{lc}
\hline Variables & Pearson correlation coefficient \\
\hline GDPmp/diversity index & $0.746^{\star}$ \\
\hline GDPmp growth rate/diversity index & $0.551^{\star \star}$ \\
\hline
\end{tabular}

Source: Prepared by the authors, on the basis of the National Institute of Statistics and Censuses (INDEC) and the Dynamic Employment Analysis Database (BADE).

Note: Statistically significant relationships: ${ }^{\star \star} 0.05 ;{ }^{*} 0.10$.

Far from being homogeneous, the Argentine territory shows marked structural heterogeneity, reflected in historical economic and territorial inequality. This, in turn, is a result of diversity of resources, population density, industrial localization and urbanization of certain geographical areas (Zalduendo, 1975; Gatto, 2007). These inequalities can also be seen in industrial productive diversity (see map 1).

The major administrative areas of the country - the city of Buenos Aires, and the provinces of Buenos Aires, Santa Fe and Córdoba - are the most diverse, along with San Luis and Neuquén. In contrast, some of the agro-industrial provinces - Salta, Jujuy, Entre Ríos, Mendoza and Río Negroare the least diverse, as the food industry accounts for around $60 \%$ of industrial employment. ${ }^{7}$ The situation is similar in Tierra del Fuego, where the radio and television manufacturing industry accounts for $60 \%$ of industrial employment.

7 Considering the degree of production development of some provinces (such as Mendoza or Entre Ríos), it is possible that there is high diversity within the food industry (related diversity), which cannot be captured by the diversity indicator used (inverse of the Herfindahl-Hirschman index $(\mathrm{HHI})$ ) with employment data disaggregated at the two-digit level of ISIC, rev. 3.1. 
Map 1

Argentina: degree of productive diversity (1/HHI), 2012

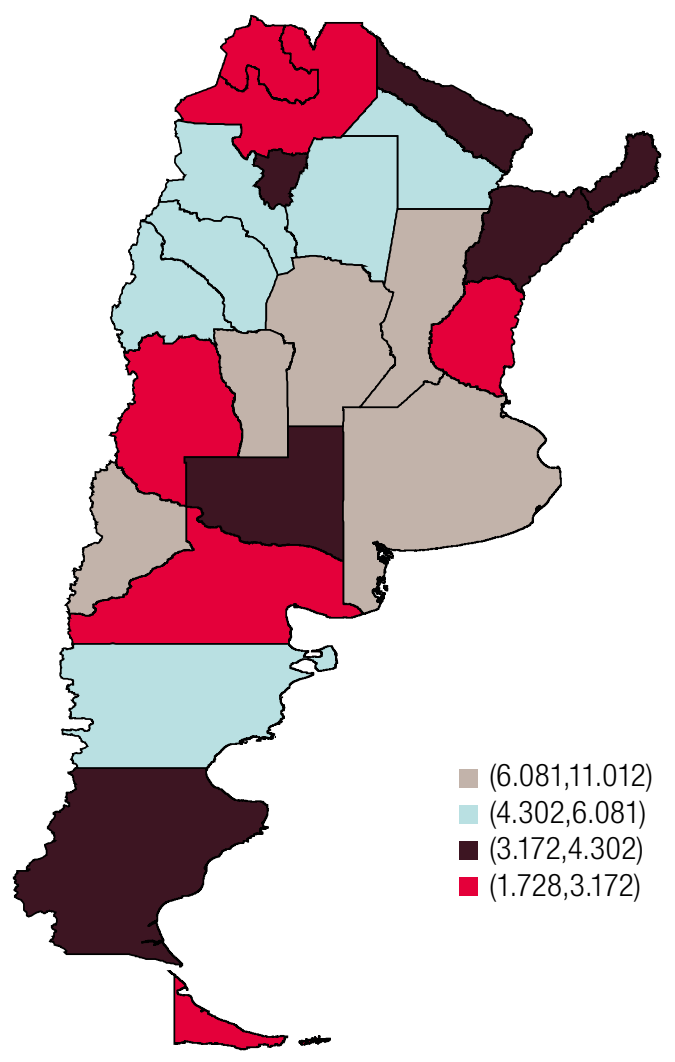

Source: Prepared by the authors, on the basis of the Dynamic Employment Analysis Database (BADE).

The high diversity of the city of Buenos Aires and the central provinces (Buenos Aires, Santa Fe and Córdoba) has been a structural and relatively stable feature in recent years (see table 4). Conversely, in the provinces with frameworks to promote industrial activity (San Luis, San Juan, La Rioja and Catamarca) diversity has decreased, possibly owing to the declining impact of such frameworks on the less traditional sectors in each region (Donato, 2007). In Tierra del Fuego, diversity has dropped sharply since 2009, as a result of the relative increase in employment in the sectors benefiting from special frameworks over the period (radio and television equipment, textiles, leather and footwear).

Figure 2 shows the evolution of average diversity by the provincial groups listed in table 4, together with the national index. The national trend is set by the most diverse regions, which are the ones with the greatest relative weight in terms of employment. The other groups show a similar trend, i.e. they show procyclical patterns, except for the provinces with industrial promotion policies, whose diversity has declined steadily. ${ }^{8}$

An increase in the degree of diversity may be associated with one of two phenomena: either growth in employment in less traditional sectors (with steady or slackening growth in traditional sectors); or a fall in employment in the main sectors. One example of the former is the province of Chubut, where the increase in diversity is linked to growth in non-traditional sectors such as metal products (division 28) or non-metallic minerals (division 26). Chaco is an example of the latter, where the increase in diversity is the result of a fall in employment in the textile industry (division 17) (see figure 3). The causes and effects of diversity are likely to change in both cases and future research on the subject should consider this. ${ }^{9}$

\footnotetext{
8 The evolution of the productive diversity index by province is set out in annex 3 .

9 In the models in section VI.2 it was not possible to incorporate this, since Chaco is the only province with a pattern linked to the second group. It is therefore not possible to estimate different regressions for each group or to incorporate a binary variable into the fixed-effects panel data regressions.
} 
Table 4

Argentina: provincial productive diversity index, 1996-2012

\begin{tabular}{|c|c|c|c|c|c|}
\hline Provincial classification & Province & $\begin{array}{l}\text { Productive diversity } \\
\text { index, } 1996\end{array}$ & $\begin{array}{l}\text { Productive diversity } \\
\text { index, } 2012\end{array}$ & $\begin{array}{c}\text { Change } \\
(1996-2012)\end{array}$ & $\begin{array}{c}\text { Coefficient } \\
\text { of variation } \\
\text { (1996-2012) }\end{array}$ \\
\hline \multirow{4}{*}{$\begin{array}{l}\text { Production and } \\
\text { consumption hub }\end{array}$} & City of Buenos Aires & 9.65 & 11.01 & $\uparrow$ & 0.07 \\
\hline & Buenos Aires & 10.29 & 10.14 & $\downarrow$ & 0.03 \\
\hline & Santa Fe & 5.73 & 6.99 & $\uparrow$ & 0.06 \\
\hline & Córdoba & 5.57 & 6.09 & $\uparrow$ & 0.06 \\
\hline \multirow[t]{5}{*}{ Promotes industry } & San Luis & 10.45 & 7.52 & $\downarrow$ & 0.09 \\
\hline & San Juan & 5.55 & 5.94 & $\uparrow$ & 0.04 \\
\hline & Catamarca & 6.58 & 5.41 & $\downarrow$ & 0.08 \\
\hline & La Rioja & 5.68 & 5.19 & $\downarrow$ & 0.05 \\
\hline & Tierra del Fuego & 4.33 & 2.57 & $\downarrow$ & 0.15 \\
\hline \multirow[t]{7}{*}{ Agro-industrial complex } & Tucumán & 3.43 & 3.44 & $\uparrow$ & 0.03 \\
\hline & La Pampa & 4.68 & 3.23 & $\downarrow$ & 0.17 \\
\hline & Entre Ríos & 2.61 & 3.10 & $\uparrow$ & 0.08 \\
\hline & Salta & 2.75 & 2.77 & $\uparrow$ & 0.04 \\
\hline & Río Negro & 2.53 & 2.54 & $\uparrow$ & 0.09 \\
\hline & Mendoza & 2.45 & 2.33 & $\downarrow$ & 0.06 \\
\hline & Jujuy & 2.27 & 1.72 & $\downarrow$ & 0.11 \\
\hline \multirow[t]{3}{*}{ Oil and fishing complex } & Neuquén & 6.57 & 6.58 & $\uparrow$ & 0.04 \\
\hline & Chubut & 4.59 & 5.98 & $\uparrow$ & 0.10 \\
\hline & Santa Cruz & 5.25 & 4.06 & $\downarrow$ & 0.15 \\
\hline \multirow{5}{*}{$\begin{array}{l}\text { Forestry and } \\
\text { textile complexes }\end{array}$} & Santiago del Estero & 4.28 & 4.43 & $\uparrow$ & 0.04 \\
\hline & Chaco & 4.55 & 6.06 & $\uparrow$ & 0.08 \\
\hline & Formosa & 4.85 & 4.17 & $\downarrow$ & 0.13 \\
\hline & Corrientes & 3.74 & 4.06 & $\uparrow$ & 0.08 \\
\hline & Misiones & 3.88 & 4.00 & $\uparrow$ & 0.05 \\
\hline
\end{tabular}

Source: Prepared by the authors, on the basis of the Dynamic Employment Analysis Database (BADE).

Figure 2

Argentina: industrial diversity (1/HHI) by groups of provinces

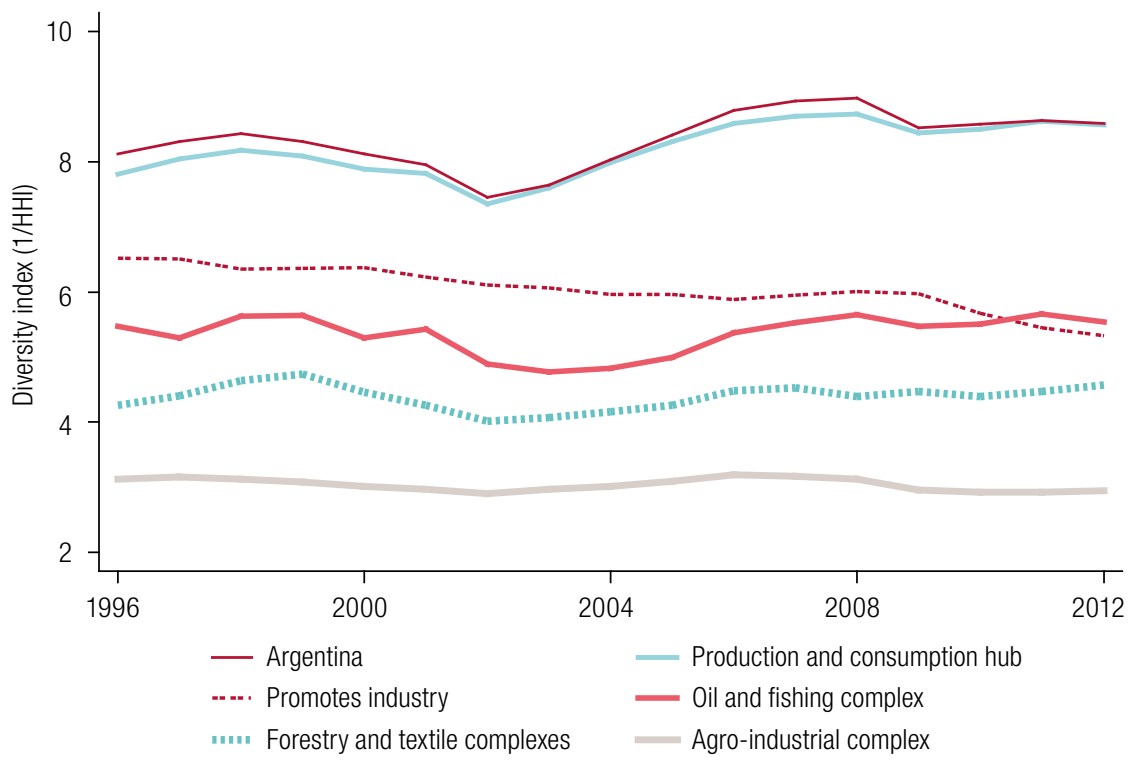

Source: Prepared by the authors, on the basis of the Dynamic Employment Analysis Database (BADE). 
Figure 3

Argentina (Chubut and Chaco): economic activities by share of total industrial employment, 1996 and 2012

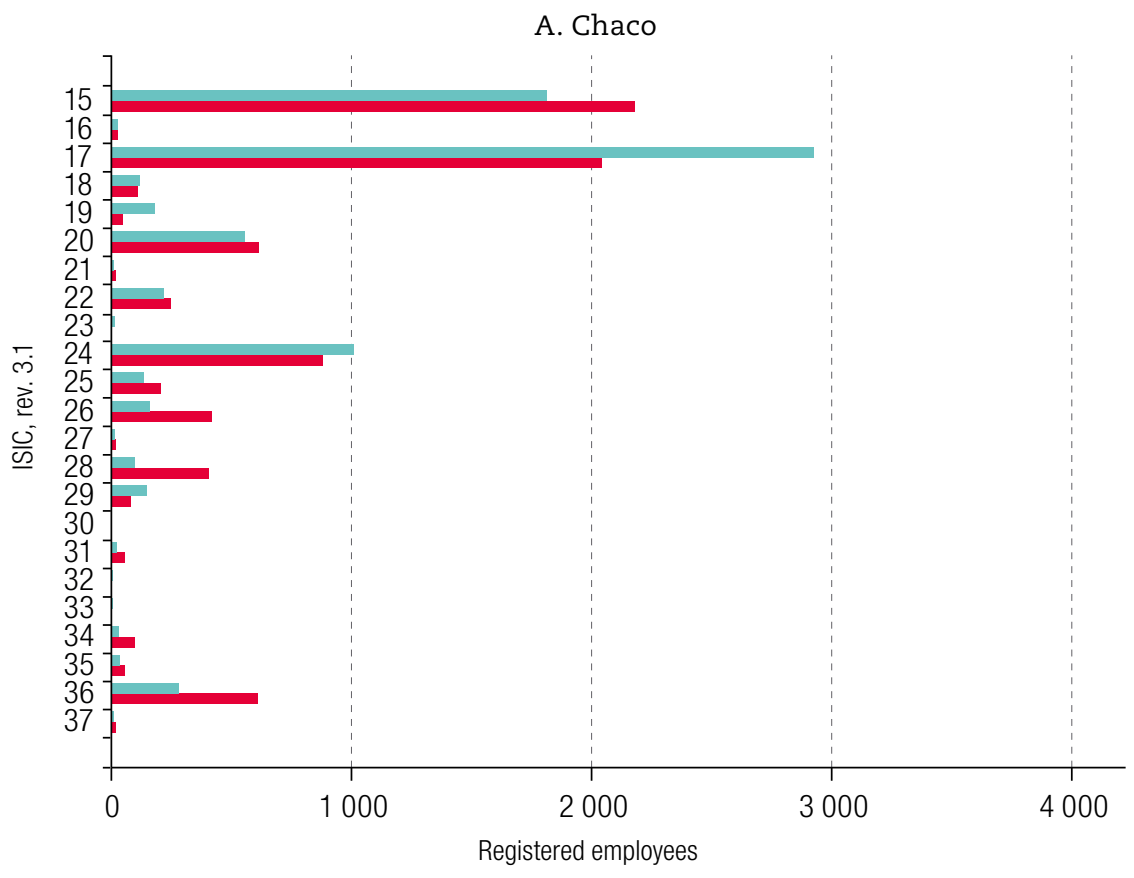

B. Chubut

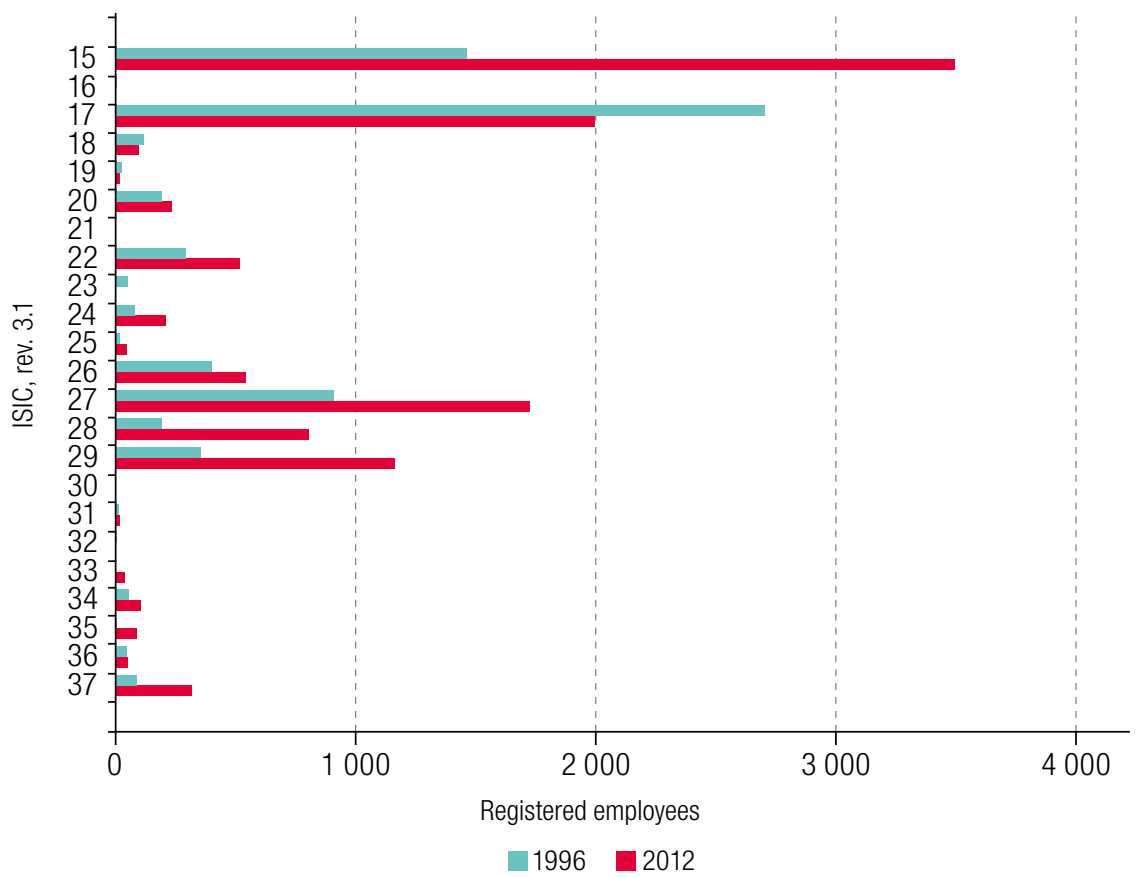

Source: Prepared by the authors, on the basis of the Dynamic Employment Analysis Database (BADE).

Note: Only two cases are included that contrast the two described causes of increased regional diversity: (a) employment growth in less traditional sectors and (b) declining employment in traditional sectors. 


\section{Economic factors linked to regional productive diversity}

To identify the economic factors associated with the degree of regional diversity, a fixed-effects panel data model is estimated. This type of model was preferred to a random-effects model since the null hypothesis of the Hausman test (Hausman, 1978) was rejected. ${ }^{10}$ Table 5 shows the results of the estimation, which include dummy variables by year to capture the time effects. The explanatory variables used have been lagged by one period as a strategy to deal with the potential problem of endogeneity (Bebczuk and Berrettoni, 2006).

Most of the estimated coefficients are statistically significant and with the expected sign, in accordance with the specialized literature. Firstly, there is a direct relationship between the regions' per capita products and their productive diversity. This confirms that the degree of regional development is positively associated with regional productive diversity. ${ }^{11}$

Table 5

Argentina: factors associated with the diversity of regional industry (model 1)

\begin{tabular}{lc}
\hline Factors & Model 1 \\
\hline Per capita GGP & $84.8968^{*}$ \\
\cline { 2 - 2 } & $(34.8276)$ \\
\hline Density & $0.9827^{\star \star *}$ \\
\hline R\&D expenditure & $(-0.1433)$ \\
\hline Share of exports & 0.2095 \\
\hline Entry of industrial firms & $(-0.1533)$ \\
\hline Exit of industrial firms & $0.0552^{*}$ \\
\cline { 2 - 2 } & $(-0.0211)$ \\
\hline Constant & 0.0000 \\
\hline F-test & $(-0.0002)$ \\
\hline $\mathrm{R}^{2}$ (W) & $-0.0008^{\star}$ \\
\hline
\end{tabular}

Source: Prepared by the authors.

Notes: Significance: ${ }^{\star} p<0.05 ;{ }^{\star \star} p<0.01 ;{ }^{* \star \star} p<0.001 ; 378$ observations; fixed effects by province, dummy variables by year; dependent variable: productive diversity index; variables lagged by one period; robust standard errors in parentheses.

Population density (a proxy variable for the level of urbanization) is directly correlated with diversity. This is evidence that urbanization economies may be a factor associated with regional industrial diversity. There is also a positive and significant relationship between each province's share of national exports and its degree of diversity. The interpretation is that provinces with greater involvement in the external market have more capabilities and resources, increasing possibilities to expand the product range of local industry.

\footnotetext{
10 The key assumption means that in the random-effects model it cannot be assumed that the explanatory variables are independent of the error term, so if the null hypothesis is rejected, it is suggested to use a fixed-effects estimator, which always provides consistent estimates (Wooldridge, 2010). The random-effects estimates are available for consultation.

${ }^{11}$ Alternative specifications also included the quadratic term (pcGGP2) to determine whether there is a non-linear relationship between regional diversity and development, such as that observed at the country level by Imbs and Wacziarg (2003). The term was not statistically significant. This could be because Argentine regions are much more homogeneous in terms of development than the countries analysed by these authors.
} 
While a positive correlation was expected between R\&D spending and diversity, the coefficient is positive but not significant. This may be because public spending on R\&D at the provincial level in Argentina is not sufficient to encourage a change in the production structure.

Examination of the variables that capture regional industrial dynamics shows that the exit of firms decreases diversity. This indicates that exits are most frequent in the less traditional sectors of each region, either because they have fewer localization economies, limited productive or institutional capabilities to keep firms in the market, or infrastructure that is not suited to their development. In contrast, the entry of firms is not statistically significant, possibly because firms enter both traditional and non-traditional sectors in each region, thus offsetting the impact of such entries on diversity. Greater disaggregation of the business dynamics data could allow the effective identification of the sectors firms enter and exit at the provincial level, and corroborate these interpretations.

Table 6 shows the results of an alternative specification, which includes a measure of the size of the region -GGP - to analyse whether, as suggested by the specialized literature, the largest regions are also the most diverse (the measure of degree of development (pcGGP) is omitted owing to high multicollinearity). The relationship between the size of the regions and diversity is positive and significant. The rest of the results remain the same.

Table 6

Argentina: factors associated with the diversity of regional industry (model 2)

\begin{tabular}{lc}
\hline Factors & Model 2 \\
\hline GGP & $0.00001^{\star}$ \\
\hline Density & $(0.000)$ \\
\hline R\&D expenditure & $0.8387^{\star * \star}$ \\
\hline Share of exports & $0.118)$ \\
\hline Entry of industrial firms & 0.2237 \\
\hline Exit of industrial firms & $0.181)$ \\
\hline Constant & $0.0600^{\star}$ \\
\hline F-test & $(0.030)$ \\
\hline $\mathrm{R}^{2}(\mathrm{~W})$ & -0.0001 \\
\hline
\end{tabular}

Source: Prepared by the authors.

Note: Significance: * $p<0.05 ;{ }^{* \star} p<0.01 ;{ }^{* \star *} p<0.001 ; 378$ observations; fixed effects by province, dummy variables by year; dependent variable: productive diversity index; variables lagged by one period; robust standard errors in parenthesis.

To verify the robustness of the results, various alternative specifications of the models are presented in table 7. Firstly, since price indices are not available for all provinces, as an alternative to Argentina's IPI, the IPI of the city of Buenos Aires is used to deflate the GGP data (see table 7). The results remain the same, using GGP both as a measure of development (per capita GGP - model 3) and as a proxy for size (GGP - model 4). 
Table 7

Argentina: factors associated with the diversity of regional industry (models 3 and 4)

\begin{tabular}{|c|c|c|}
\hline Factors & Model 3 & Model 4 \\
\hline \multirow[t]{2}{*}{ Per capita GGP (deflated based on the IPI for the city of Buenos Aires) } & $87.6756^{\star}$ & \\
\hline & $(32.6031)$ & \\
\hline \multirow[t]{2}{*}{ GGP (deflated based on the IPI for the city of Buenos Aires) } & & $0.0001^{*}$ \\
\hline & & $(0.000)$ \\
\hline \multirow[t]{2}{*}{ Density } & $1.0064^{\star \star \star}$ & $0.839^{* \star *}$ \\
\hline & $(-0.1425)$ & (0.118) \\
\hline \multirow[t]{2}{*}{ R\&D expenditure } & 0.2134 & 0.224 \\
\hline & $(-0.151)$ & $(0.181)$ \\
\hline \multirow[t]{2}{*}{ Share of exports } & $0.0549^{*}$ & $0.061^{*}$ \\
\hline & $(-0.0213)$ & $(0.030)$ \\
\hline \multirow[t]{2}{*}{ Entry of industrial firms } & 0.0000 & 0.000 \\
\hline & $(-0.0002)$ & $(0.000)$ \\
\hline \multirow[t]{2}{*}{ Exit of industrial firms } & $-0.0008^{*}$ & $-0.001^{\star *}$ \\
\hline & $(-0.0003)$ & $(0.000)$ \\
\hline \multirow[t]{2}{*}{ Constant } & 1.9886 & 2.375 \\
\hline & (1.5798) & $(1.746)$ \\
\hline F-test & $58.70^{\star \star \star}$ & $354.07^{\star \star \star}$ \\
\hline$R^{2}(w)$ & 0.38 & 0.33 \\
\hline
\end{tabular}

Source: Prepared by the authors.

Note: Significance: * $p<0.05 ;{ }^{* \star} p<0.01 ;{ }^{\star \star \star} p<0.001 ; 378$ observations; fixed effects by province, dummy variables by year; dependent variable: productive diversity index; variables lagged by one period; robust standard errors in parentheses.

Another test of robustness consists of estimating regressions excluding provinces whose main activity accounts for more than 50\% of regional industrial employment (Tucumán, La Pampa, Entre Ríos, Salta, Río Negro, Mendoza, Jujuy and Tierra del Fuego). It is possible that in these provinces the pattern in the index is related to factors that affect the trend in the main sector and not factors linked to diversity. As in the base estimated regression, most of the explanatory variables remain statistically significant and show the expected signs (see table 8). The results are presented taking the constant pcGGP, deflated by the IPI of Argentina (model 5) and by the IPI of the city of Buenos Aires (model 6).

Table 8

Argentina: factors associated with the diversity of regional industry (excluding provinces with highly concentrated employment)

\begin{tabular}{|c|c|c|}
\hline Factors & Model 5 & Model 6 \\
\hline \multirow[t]{2}{*}{ Per capita GGP (deflated based on the IPI for Argentina) } & $101.409^{\star \star}$ & \\
\hline & $(29.3258)$ & \\
\hline \multirow[t]{2}{*}{ Per capita GGP (deflated based on the IPI for the city of Buenos Aires) } & & $98.9882^{\star *}$ \\
\hline & & $(30.6885)$ \\
\hline \multirow[t]{2}{*}{ Density } & $4.6024^{\star \star}$ & $4.5532^{\star *}$ \\
\hline & $(1.4499)$ & (1.5046) \\
\hline \multirow[t]{2}{*}{ R\&D expenditure } & $0.4071^{*}$ & $0.4008^{*}$ \\
\hline & $(0.1698)$ & $(0.1712)$ \\
\hline \multirow[t]{2}{*}{ Share of exports } & $0.0399^{*}$ & $0.0407^{\star}$ \\
\hline & $(0.0208)$ & (0.0206) \\
\hline \multirow[t]{2}{*}{ Entry of industrial firms } & 0.0001 & 0.0001 \\
\hline & $(0.0002)$ & $(0.0002)$ \\
\hline \multirow[t]{2}{*}{ Exit of industrial firms } & $-0.0007^{\star}$ & $-0.0007^{*}$ \\
\hline & $(0.0003)$ & $(0.0003)$ \\
\hline \multirow[t]{2}{*}{ Constant } & 0.1987 & 0.2928 \\
\hline & (1.9722) & (1.9928) \\
\hline F-test & $6.96^{\star \star \star}$ & $9.28^{\star \star \star}$ \\
\hline $\mathrm{R}^{2}(\mathrm{~W})$ & 0.42 & 0.42 \\
\hline
\end{tabular}

Source: Prepared by the authors.

Note: Significance: ${ }^{\star} p<0.05 ;{ }^{\star \star} p<0.01 ;{ }^{\star \star \star} p<0.001 ; 256$ observations; fixed effects by province, dummy variables by year; dependent variable: productive diversity index; variables lagged by one period; robust standard errors in parentheses. 
In order to control possible path dependence in the diversification process, a dependent variable lagged by one period is included as an independent variable, modelled on the Arellano-Bond estimator for dynamic panels. Although the generalized method of moments (GMM) model is globally significant, the variables included are not statistically significant, which may be evidence of multicollinearity between the variables mentioned (see table 9). Although instrumental variables estimation could be appropriate in this case, it cannot be used because of the low number of observations. ${ }^{12}$

Table 9

Argentina: factors associated with the diversity of regional industry (dynamic model)

\begin{tabular}{lc}
\hline Factors & Model 7 \\
\hline Diversity index (lagged one period) & -0.5481 \\
\cline { 2 - 2 } & $(0.7465)$ \\
\hline Per capita GGP & -17.06 \\
\hline Density & $(441.1592)$ \\
\hline R\&D expenditure & -13.8913 \\
& $(14.1142)$ \\
\hline Share of exports & 0.4415 \\
& $(0.9466)$ \\
\hline Entry of industrial firms & -0.0098 \\
& $(0.0468)$ \\
\hline Exit of industrial firms & 0.0003 \\
& $(0.0004)$ \\
\hline Constant & -0.0004 \\
& $(0.0005)$ \\
\hline Wald test & 7.3263 \\
\hline
\end{tabular}

Source: Prepared by the authors.

Note: Significance: * $p<0.05 ;{ }^{* \star} p<0.01 ;{ }^{* \star} p<0.001$ GMM; 378 observations; Lag (1) dummy variable by year; dependent variable: productive diversity index; variables lagged by one period; robust standard errors in parentheses.

\section{VII.Concluding remarks}

The specialized literature considers productive diversity to be key to the design of industrial policies for regional development. A more diverse productive structure is associated with an environment that is conducive to new investment, greater innovation and the transfer of knowledge, among other positive effects. This article contributes empirically to the study of productive diversity through a regional approach with updated data for all Argentine provinces. In particular, it analyses industrial diversity in both static and dynamic terms: on one hand, it describes and quantifies the degree of regional productive diversity in Argentina and how it evolved in the 1996-2012 period; and on the other, it examines the relationship between this phenomenon and some associated regional economic factors.

In static terms, the most diverse administrative areas in the country are the city of Buenos Aires and the provinces of Buenos Aires, Santa Fe, Córdoba, San Luis and Neuquén. This result may be associated with the higher level of urbanization in these regions, with greater productive, institutional and organizational capabilities that encourage the establishment of a large number of enterprises in various sectors, or with the existence of specific industrial policy incentives. In contrast to this group, the

\footnotetext{
12 For example, He (2009) uses data from 20,035 firms; Elhiraika and Mbate (2014) work with information from 53 countries; Cadot,
} Carrère and Strauss-Kahn (2011) use export data for 79 countries. 
provinces with a less diverse industrial structure are those with an agrifood base (Tucumán, La Pampa, Entre Ríos, Salta, Río Negro, Mendoza and Jujuy), where the food and beverage sector accounts for more than half of industrial employment.

In dynamic terms, productive diversity is a procyclical phenomenon, both at the national level and in most regions. This result, together with the negative impact on diversity of firms' exits, highlights the need for a stable growth path to achieve structural change based on productive diversity. This also raises a number of questions about the impact of macroeconomic policies (exchange rate, trade protection and fiscal policies, among others) on productive diversity, at the national and regional levels.

The provinces that have frameworks to promote industrial activity (San Luis, Catamarca, San Juan, La Rioja and Tierra del Fuego) are a special case, in which industrial diversity is not procyclical but is in steady decline. In some instances, this may be linked to the current inability of such frameworks to drive changes in the production structure that entail growth in non-traditional sectors, while in others the greater specialization is related to the sizeable incentives recently received to develop certain industries, such as radio and television equipment manufacturers in Tierra del Fuego.

The results of the econometric estimations indicate that the industrial diversity of the provinces is positively associated with their level of development, the size of the region and a higher level of urbanization. This restricts the ability of specific policies to promote productive diversification, given that these structural characteristics are difficult to change in the short term. Regional industrial diversity is also directly related to territorial capabilities, which may be boosted through medium-term industrial policies.

Conversely, the exit of firms is negatively associated with the degree of diversity. This may be because of the closure of firms in non-traditional sectors, whose external economies (such as specialized labour market and suppliers) and supporting institutions are not sufficiently consolidated. In this regard, policies to retain firms in less traditional sectors may be more effective in increasing diversity than those focused on the entry of new businesses in those sectors.

Some dimensions that have not been addressed in this article may give rise to future research on the subject. Firstly, greater disaggregation of the data (three or four digits in ISIC, rev. 3.1), or study of the primary, commercial and service sectors would provide a more in-depth understanding of the phenomenon, given that the relative importance of industry differs sharply between provinces. Another point of interest is whether diversity occurs in related or unrelated industries, since international literature indicates that these two types of diversity are driven by different sources and have different effects. In the same vein, the availability of business demography data with greater sector disaggregation would make it possible to determine the sectors (traditional or not) that businesses actually enter and exit.

\section{Bibliography}

Al-Marhubi, F. (2000), "Export diversification and growth: an empirical investigation", Applied Economics Letters, vol. 7, No. 9, Abingdon, Taylor \& Francis.

Artopoulos, A., D. Friel and J. C. Hallak (2013), "Export emergence of differentiated goods from developing countries: export pioneers and business practices in Argentina", Journal of Development Economics, vol. 105, Amsterdam, Elsevier.

Aw, B. and G. Batra (1998), "Firm size and the pattern of diversification", International Journal of Industrial Organization, vol. 16, No. 3, Amsterdam, Elsevier.

Baldwin, J. R. and others (2000), "Patterns of corporate diversification in Canada: an empirical analysis", Research Paper, No. 150, Ottawa, Statistics Canada.

Baltagi, B. (2008), Econometric Analysis of Panel Data, West Sussex, John Wiley \& Sons.

Bebczuk, R. and D. Berrettoni (2006), "Explaining export diversification: an empirical analysis", Documentos de Trabajo, No. 65, La Plata, National University of La Plata. 
Beckstead, D. and W. M. Brown (2003), "From Labrador City to Toronto: the industrial diversity of Canadian cities, 1992 to 2002", Insights on the Canadian Economy, Ottawa, Ministry of Industry.

Bielschowsky, R., M. Izam and N. Mulder (2011), "Dos estudios de la evolución del pensamiento de la CEPAL sobre la diversificación productiva y la inserción internacional (1949-2008)", International Trade series, No. 112 (LC/L.3415), Santiago, Economic Commission for Latin America and the Caribbean (ECLAC).

Bishop, P. and P. Gripaios (2007), "Explaining spatial patterns of industrial diversity: an analysis of sub-regions in Great Britain", Urban Studies, vol. 44, No. 9, Thousand Oaks, Sage.

Boschma R. (2004), "Competitiveness of regions from an evolutionary perspective", Regional Studies, vol. 38 , No. 9, Abingdon, Taylor \& Francis.

Boschma, R. and G. Capone (2015), "Institutions and diversification: related versus unrelated diversification in a varieties of capitalism framework", Research Policy, vol. 44, No. 10, Amsterdam, Elsevier.

Boschma, R. and S. lammarino (2007), "Related variety and regional growth in Italy", SPRU Electronic Working Paper, No. 162, Brighton, University of Sussex.

Boschma, R., A. Minondo and M. Navarro (2013), "The emergence of new industries at the regional level in Spain: a proximity approach based on product relatedness", Economic Geography, vol. 89, No. 1, Abingdon, Taylor \& Francis.

Cadot, O., C. Carrère and V. Strauss-Kahn (2011), "Export diversification: what's behind the hump?", Review of Economics and Statistics, vol. 93, No. 2, Cambridge, MIT Press.

Capello, R. (2006), "La economía regional tras cincuenta años: desarrollos teóricos recientes y desafíos futuros", Journal of Regional Research, No. 9, Alcalá de Henares, University of Alcalá.

Castellacci, F. (2007), "Technological regimes and sectoral differences in productivity growth", Industrial and Corporate Change, vol. 16, No. 6, Oxford, Oxford University Press.

Castillo, V. and others (2004), "Observatorio de empleo y dinámica empresarial en Argentina", Production Development series, No. 148 (LC/L.2072-P), Economic Commission for Latin America and the Caribbean (ECLAC).

Crépon, B., E. Duguet and J. Mairesse (1998), "Research, innovation and productivity: an econometric analysis at the firm level", Economics of Innovation and New Technology, vol. 7, No. 2, Abingdon, Taylor \& Francis.

De Benedictis, L., M. Gallegati and M. Tamberi (2009), "Overall trade specialization and economic development: countries diversify", Review of World Economics, vol. 145, No. 1, New York, Springer.

Dewhurst, J. H. L. and P. McCann (2002), "A comparison of measures of industrial specialization for travel-to-work areas in Great Britain, 1981-1997", Regional Studies, vol. 36, No. 5, Abingdon, Taylor \& Francis.

Donato, V. (2007), "Políticas públicas y localización industrial en Argentina", Revista OIDLES, vol. 1, No. 1, Malaga, University of Malaga.

Dumais, G., G. Ellison and E. Glaeser (2002), "Geographic concentration as a dynamic process", The Review of Economics and Statistics, vol. 84, No. 2, Cambridge, MIT Press.

Duranton, G. and D. Puga (2000), "Diversity and specialisation in cities: why, where and when does it matter?", Urban Studies, vol. 37, No. 3, Thousand Oaks, Sage.

Elhiraika, A. and M. Mbate (2014), "Assessing the determinants of export diversification in Africa", Applied Econometrics and International Development, vol. 14, No. 1, University of Santiago de Compostela.

Essletzbichler, J. and D. L. Rigby (2007), "Exploring evolutionary economic geographies", Journal of Economic Geography, vol. 7, No. 5, Oxford, Oxford University Press.

Filipescu, D. A. and others (2013), "Technological innovation and exports: unpacking their reciprocal causality", Journal of International Marketing, vol. 21, No. 1, Thousand Oaks, Sage.

Frenken, K., F. van Oort and T. Verburg (2007), "Related variety, unrelated variety and regional economic growth", Regional Studies, vol. 41, No. 5, Abingdon, Taylor \& Francis.

Frenken, K. and others (2004), "Variety and regional economic growth in the Netherlands", Papers in Evolutionary Economic Geography, No. 0502, Utrecht, Utrecht University.

Fritzsche, F. J. and M. Vio (2000), "Especialización y diversificación industrial en la Región Metropolitana de Buenos Aires", EURE, vol. 26, No. 79, Santiago, Pontifical Catholic University of Chile.

Fujita, M. and P. Krugman (2004), "La nueva geografía económica: pasado, presente y futuro", Journal of Regional Research, No. 4, Alcalá de Henares, University of Alcalá.

Gatto, F. (2007), "Crecimiento económico y desigualdades territoriales: algunos límites estructurales para lograr una mayor equidad", Crisis, recuperación y nuevos dilemas: la economía argentina 2002-2007 (LC/W.165-LC/BUE/W.20), B. Kosacoff (ed.), Santiago, Economic Commission for Latin America and the Caribbean (ECLAC). 
Ghosh, A. and J. Ostry (1994), "Export instability and the external balance in developing countries", IMF Working Paper, No. 94/8, Washington, D.C. International Monetary Fund.

Glaeser, E. L. and others (1992), "Growth in cities", Journal of Political Economy, vol. 100, No. 6, Chicago, The University of Chicago.

Guesnier, B. (1994), "Regional variations in new firm formation in France", Regional Studies, vol. 28, No. 4, Abingdon, Taylor \& Francis.

Haddad, M., J. J. Lim and C. Saborowski (2010), "Trade openness reduces growth volatility when countries are well diversified”, World Bank Policy Research Working Paper, No. WPS 5222, Washington, D.C., World Bank.

Hammouda, H. and others (2006), "Diversification: towards a new paradigm for Africa's development", ATPC Work in Progress, No. 35, Adis Ababa, Economic Commission for Africa.

Hausman, J. A. (1978), "Specification tests in econometrics", Econometrica, vol. 46, No. 6, Cleveland, The Econometric Society.

$\mathrm{He}, \mathrm{X}$. (2009), "Corporate diversification and firm value: evidence from post-1997 data", International Review of Finance, vol. 9, No. 4, Hoboken, Wiley.

Henderson, V., A. Kuncoro and M. Turner (1995), "Industrial development in cities", Journal of Political Economy, vol. 103, No. 5, Chicago, The University of Chicago Press.

Herzer, D. and F. Nowak-Lehnmann (2006), "What does export diversification do for growth? An econometric analysis", Applied Economics, vol. 38, No. 15, Abingdon, Taylor \& Francis.

Hesse, H. (2009), "Export diversification and economic growth", Breaking into New Markets: Emerging Lessons for Export Diversification, R. S. Newfarmer, W. Shaw and P. Walkenhorst (eds.), Washington, D.C., World Bank.

Hidalgo, C. A. and R. Hausmann (2010), "Country diversification, product ubiquity, and economic divergence", CID Working Paper, No. 201, Cambridge, Center for International Development, Harvard University.

Hidalgo, C. A. and others (2007), "The product space conditions the development of nations", Science, vol. 317, No. 5837, Washington, D.C., American Association for the Advancement of Science.

Hoover, Jr., E. M. (1936), "The measurement of industrial localization", The Review of Economics and Statistics, vol. 18, No. 4, Cambridge, MIT Press.

Imbs, J. and R. Wacziarg (2003), "Stages of diversification", The American Economic Review, vol. 93, No. 1, Nashville, American Economic Association.

Kamien, M. I. and N. L. Schwartz (1975), "Market structure and innovation: a survey", Journal of Economic Literature, vol. 13, No. 1, Nashville, American Economic Association.

Klinger, B. and D. Lederman (2004), "Discovery and development: an empirical exploration of "new" products", Policy Research Working Paper, No. 3450, Washington, D.C., World Bank.

Kosacoff, B. and A. Ramos (1999), "The industrial policy debate", CEPAL Review, No. 68 (LC/G.2039-P), Santiago, Economic Commission for Latin America and the Caribbean (ECLAC).

Krugman, P. (1999), "The role of geography in development", International Regional Science Review, vol. 22, No. 2, New York, Sage.

(1998), "What's new about the new economic geography?", Oxford Review of Economic Policy, vol. 14, No. 2, Oxford, Oxford University Press.

(1995), Development, Geography and Economic Theory, Cambridge, MIT Press.

(1991), "Increasing returns and economic geography", Journal of Political Economy, vol. 99, No. 3, Chicago, The University of Chicago.

Lavarello, P. J. and M. Sarabia (2015), "La política industrial en la Argentina durante la década de 2000", Studies and Perspectives-ECLAC Office in Buenos Aires series, No. 45 (LC/L.414- LC/BUE/L.224), Santiago, Economic Commission for Latin America and the Caribbean (ECLAC).

Lawson, C. (1999), "Towards a competence theory of the region", Cambridge Journal of Economics, vol. 23, No. 2, Oxford, Oxford University Press.

Mack, E., T. Grubesic and E. Kessler (2007), "Indices of industrial diversity and regional economic composition", Growth and Change, vol. 38, No. 3, Hoboken, Wiley.

Marra, A., V. Carlei and A. L. Paglialunga (2011), "Economic diversity and industry patterns in Italian provinces: an empirical analysis", L'industria, vol. 32, No. 3, Bologna, Società editrice il Mulino.

Martin, R. and P. Sunley (2006), "Path dependence and regional economic evolution", Journal of Economic Geography, vol. 6, No. 4, Oxford, Oxford University Press. 
Mazorra, X. and A. Beccaria (2007), "Especialización productiva y empleo en Áreas Económicas Locales", Estructura productiva y empleo. Un enfoque transversal, M. Novick and H. Palomino (coords.), Buenos Aires, Ministry of Labour, Employment and Social Security.

McCann, P. and F. van Oort (2009), "Theories of agglomeration and regional economic growth: a historical review", Handbook of Regional Growth and Development Theories, R. Capello and P. Nijkamp (eds.), Cheltenham, Edward Elgar.

Ministry of Industry (2011), Plan Estratégico Industrial 2020, Buenos Aires.

Monastiriotis, V. (2000), "City size and production diversity: patterns of specialisation and diversity in the US cities, 1969-1997", Forty Congress of the European Regional Science Association, Barcelona, 29 August-1 September.

Moncayo Jiménez, E. (2001), "Evolución de los paradigmas y modelos interpretativos del desarrollo territorial", Public Administration series, No. 13 (LC/L.1587-P-LC/IP/L.190), Santiago, Economic Commission for Latin America and the Caribbean (ECLAC).

Montgomery, C. A. (1994), "Corporate diversification", The Journal of Economic Perspectives, vol. 8, No. 3, Nashville, American Economic Association.

Nachum, L. (2004), "Geographic and industrial diversification of developing country firms", Journal of Management Studies, vol. 41, No. 2, Hoboken, Wiley.

Neffke, F., M. Henning and R. Boschma (2011), "How do regions diversify over time? Industry relatedness and the development of new growth paths in regions", Economic Geography, vol. 87, No. 3, Abingdon, Taylor \& Francis.

Neffke, F. and others (2014), "Agents of structural change. The role of firms and entrepreneurs in regional diversification", Papers in Evolutionary Economic Geography, No. 1410, Utrecht, Utrecht University.

Noseleit, F. (2010), "Market selection and regional diversification - empirical regularities from German panel-data", paper presented at the Fifty Congress of the European Regional Science Association, Jönköping, 19-23 August.

Parteka, A. and M. Tamberi (2011), "Export diversification and development - empirical assessment", Quaderni di Ricerca, No. 359, Ancona, Universita' Politecnica delle Marche.

Penrose, E. T. (1959), The Theory of the Growth of the Firm, New York, Wiley.

Porta, F. (2016), "La estructura productiva argentina: problemas vigentes y desafíos pendientes", Voces en el Fénix, No. 53, Buenos Aires, University of Buenos Aires.

Ramanujan, V. and P. Varadarajan (1989), "Research on corporate diversification: a synthesis", Strategic Management Journal, vol. 10, No. 6, Hoboken, Wiley.

Reynolds, P., D. Storey and P. Westhead (1994), "Cross-national comparisons of the variation in new firm formation rates", Regional Studies, vol. 28, No. 4, Abingdon, Taylor \& Francis.

Rodgers, A. (1957), "Some aspects of industrial diversification in the United States", Economic Geography, vol. 33, No. 1, Abingdon, Taylor \& Francis.

Rojo Brizuela, S. and S. Rotondo (2006), Especialización industrial y empleo registrado en el Gran Buenos Aires, Buenos Aires, Ministry of Labour, Employment and Social Security.

Schmookler, J. (1966), Invention and Economic Growth, Cambridge, Harvard University Press.

Teece, D. J. (1980), "Economies of scope and the scope of the enterprise", Journal of Economic Behavior \& Organization, vol. 1, No. 3, Amsterdam, Elsevier.

Wooldridge, J. M. (2010), Econometric Analysis of Cross Section and Panel Data, Cambridge, MIT Press.

Zalduendo, E. (1975), "Las desigualdades económicas entre las regiones de Argentina" (CPRD-B/14), Santiago, Economic Commission for Latin America and the Caribbean (ECLAC). 


\section{Annex A1}

Table A1.1

International Standard Industrial Classification of All Economic Activities (ISIC), rev. 3.1

\begin{tabular}{|c|c|}
\hline Code & Division \\
\hline 15 & Manufacture of food products and beverages \\
\hline 16 & Manufacture of tobacco products \\
\hline 17 & Manufacture of textiles \\
\hline 18 & Manufacture of wearing apparel; dressing and dyeing of fur \\
\hline 19 & Tanning and dressing of leather; manufacture of luggage, handbags, saddlery, harness and footwear \\
\hline 20 & Manufacture of wood and of products of wood and cork, except furniture; manufacture of articles of straw and plaiting materials \\
\hline 21 & Manufacture of paper and paper products \\
\hline 22 & Publishing, printing and reproduction of recorded media \\
\hline 23 & Manufacture of coke, refined petroleum products and nuclear fuel \\
\hline 24 & Manufacture of chemicals and chemical products \\
\hline 25 & Manufacture of rubber and plastics products \\
\hline 26 & Manufacture of other non-metallic mineral products \\
\hline 27 & Manufacture of basic metals \\
\hline 28 & Manufacture of fabricated metal products, except machinery and equipment \\
\hline 29 & Manufacture of machinery and equipment n.e.c. ${ }^{\mathrm{a}}$ \\
\hline 30 & Manufacture of office, accounting and computing machinery \\
\hline 31 & Manufacture of electrical machinery and apparatus n.e.c. ${ }^{a}$ \\
\hline 32 & Manufacture of radio, television and communication equipment and apparatus \\
\hline 33 & Manufacture of medical, precision and optical instruments, watches and clocks \\
\hline 34 & Manufacture of motor vehicles, trailers and semi-trailers \\
\hline 35 & Manufacture of other transport equipment \\
\hline 36 & Manufacture of furniture; manufacturing n.e.c. ${ }^{a}$ \\
\hline 37 & Recycling \\
\hline
\end{tabular}

Source: Prepared by the authors, on the basis of United Nations, "International Standard Industrial Classification of all Economic Activities, ISIC Rev 3.1", Statistical Papers, No. 4, New York, 2002.

a Not elsewhere classified. 


\section{Annex A2}

Table A2.1

Argentina: correlation matrix

\begin{tabular}{|c|c|c|c|c|c|c|c|c|c|c|}
\hline & $\mathrm{PD}^{\mathrm{a}}$ & $\begin{array}{c}\mathrm{GGP}^{\mathrm{b}} \\
(\mathrm{IPI} B A)^{\mathrm{c}}\end{array}$ & $\begin{array}{c}\text { pc_GGPd } \\
\text { (IPI BA) }\end{array}$ & $\begin{array}{c}\text { GGP } \\
(\mathrm{IPI} A r g)^{\mathrm{e}}\end{array}$ & $\begin{array}{l}\text { pC_GGP } \\
\text { (IPIArg) }\end{array}$ & Density & $\begin{array}{l}\text { R\&D } \\
\text { expend }\end{array}$ & Sh_expo & Entry & Exit \\
\hline PD & 1.00 & & & & & & & & & \\
\hline GGP (IPI BA) & 0.69 & 1.00 & & & & & & & & \\
\hline pc_GGP (IPI BA) & 0.40 & 0.34 & 1.00 & & & & & & & \\
\hline GGP (IPI Arg) & 0.69 & 1.00 & 0.34 & 1.00 & & & & & & \\
\hline pc_GGP (IPI Arg) & 0.40 & 0.34 & 1.00 & 0.34 & 1.00 & & & & & \\
\hline Density & -0.07 & -0.12 & 0.38 & -0.12 & 0.38 & 1.00 & & & & \\
\hline R\&D_expend & 0.49 & 0.72 & 0.26 & 0.72 & 0.25 & -0.18 & 1.00 & & & \\
\hline Sh_expo & 0.50 & 0.74 & 0.01 & 0.74 & 0.01 & -0.10 & 0.53 & 1.00 & & \\
\hline Entry & 0.65 & 0.91 & 0.22 & 0.92 & 0.22 & -0.12 & 0.67 & 0.79 & 1.00 & \\
\hline Exit & 0.65 & 0.90 & 0.25 & 0.90 & 0.24 & -0.12 & 0.63 & 0.75 & 0.84 & 1.00 \\
\hline
\end{tabular}

Source: Prepared by the authors.

a Productive diversity.

b GGP.

c Buenos Aires IPI.

d Per capita GGP.

e IPI for Argentina.

f R\&D expenditure. 


\section{Annex A3}

Figure A3.1

Argentina: productive diversity index by provinces, 1996-2012

A. Production and consumption hubs
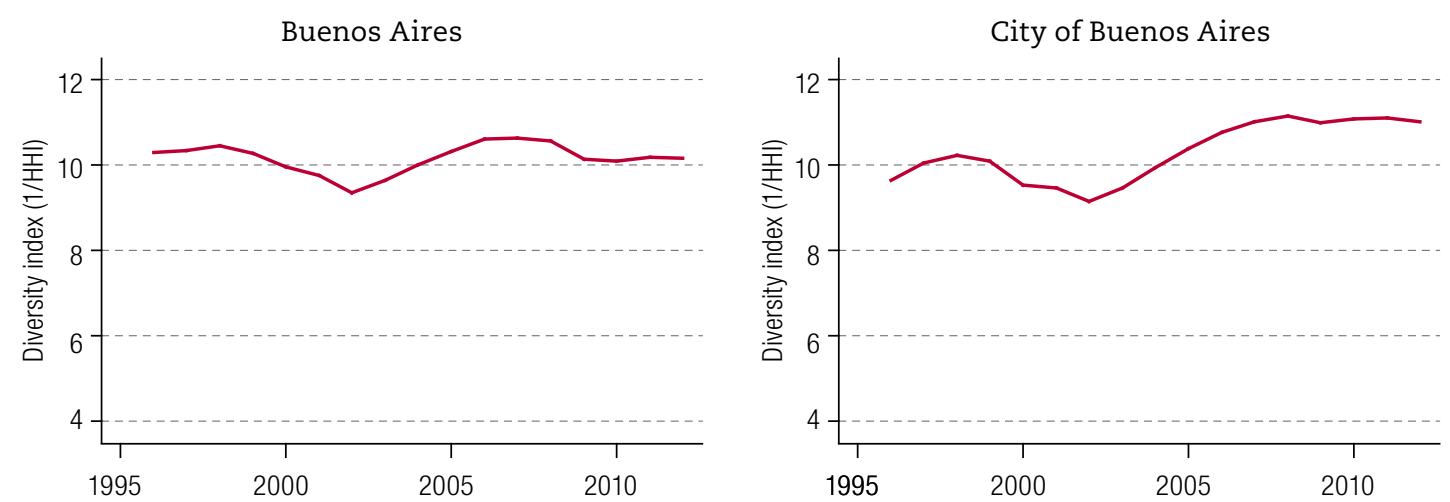

Córdoba
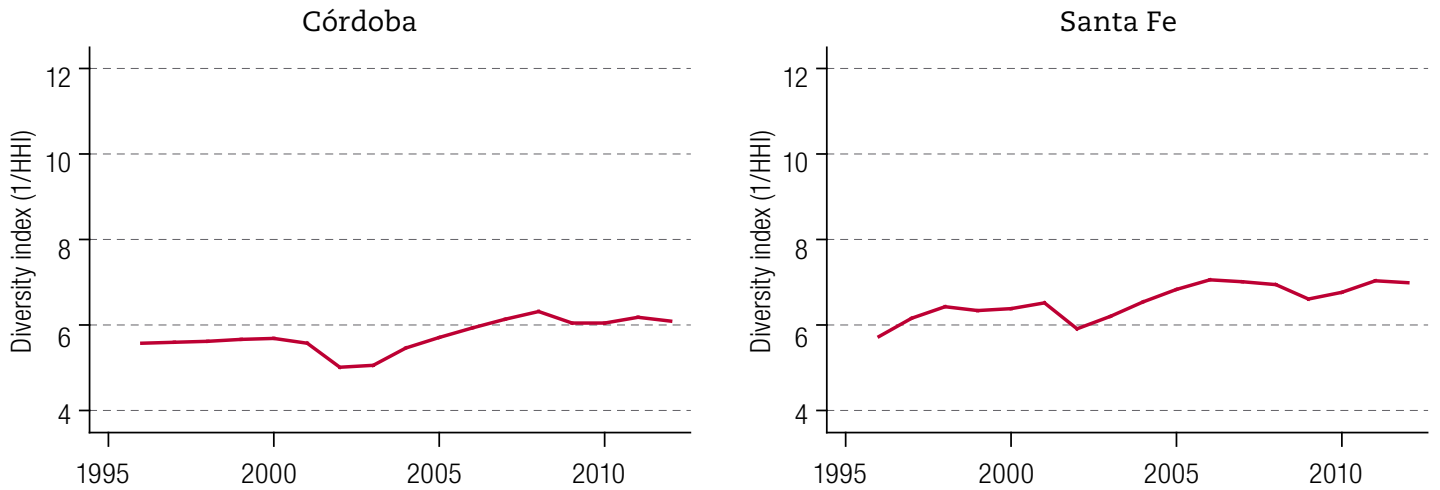

B. With frameworks to promote industrial activity
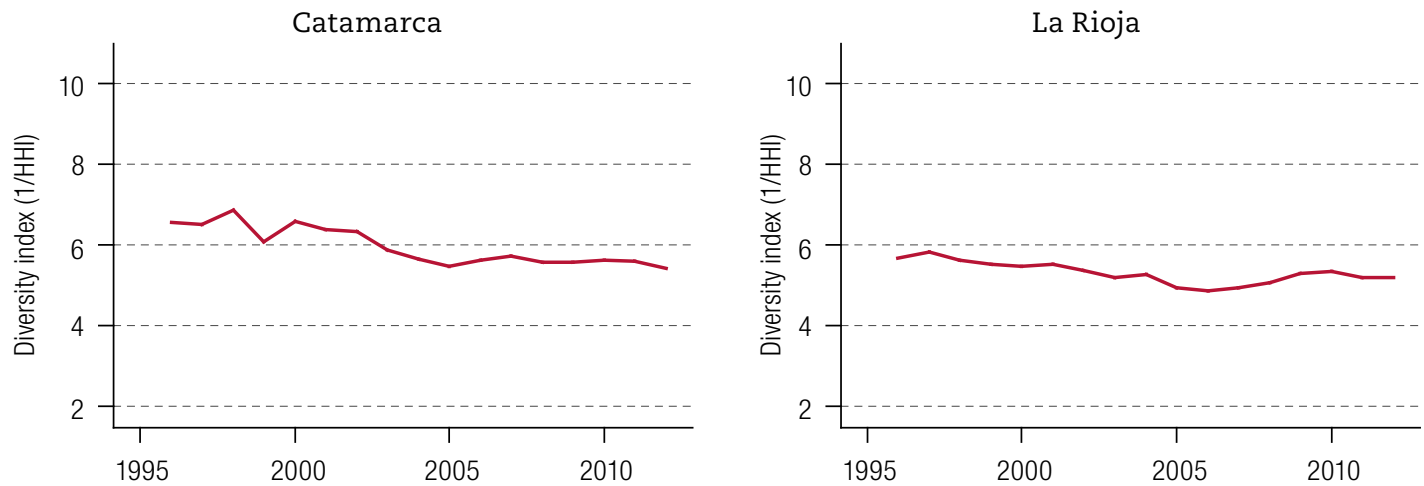
Figure A3.1 (continued)
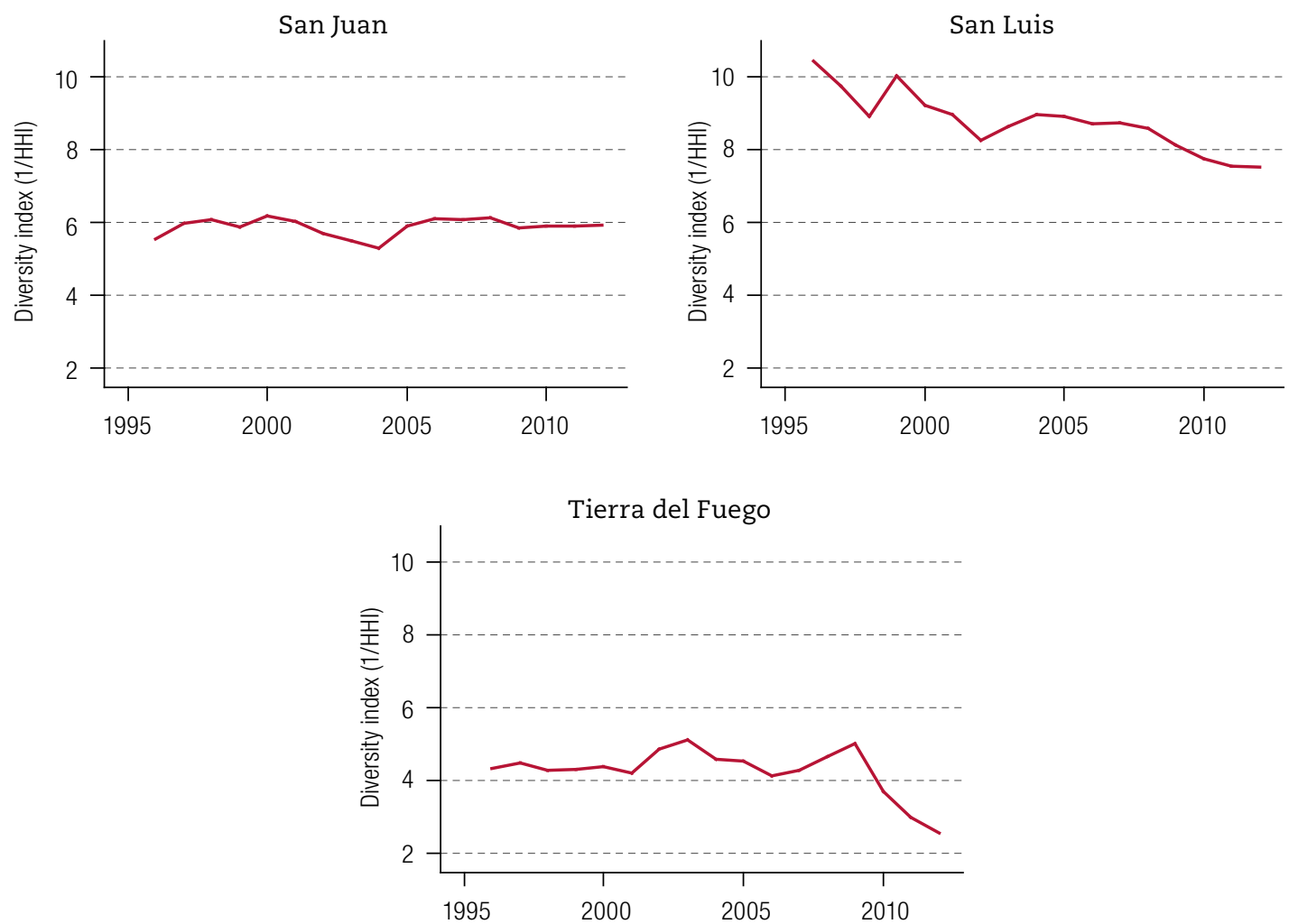

C. Agro-industrial complexes
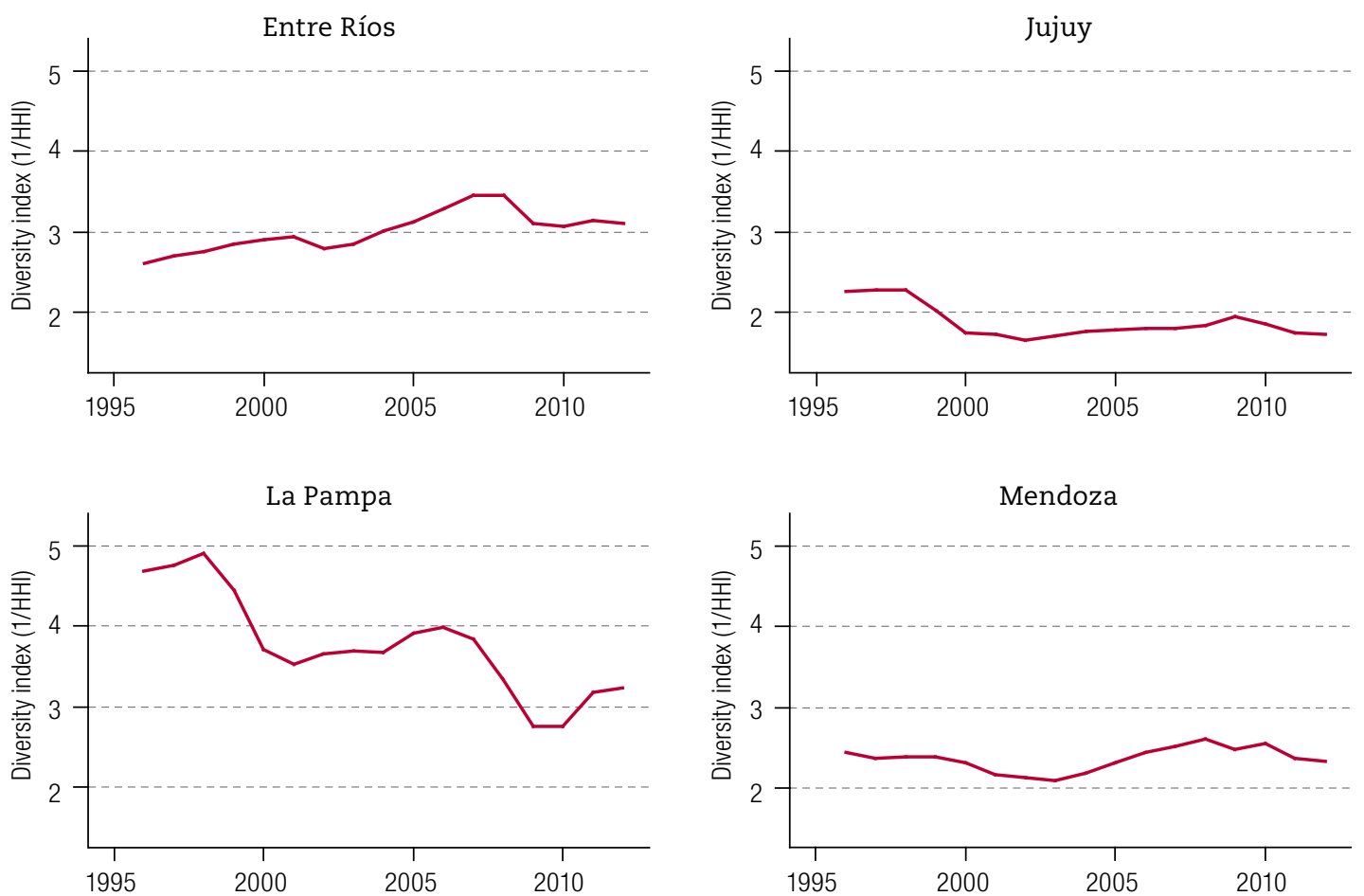
Figure A3.1 (continued)
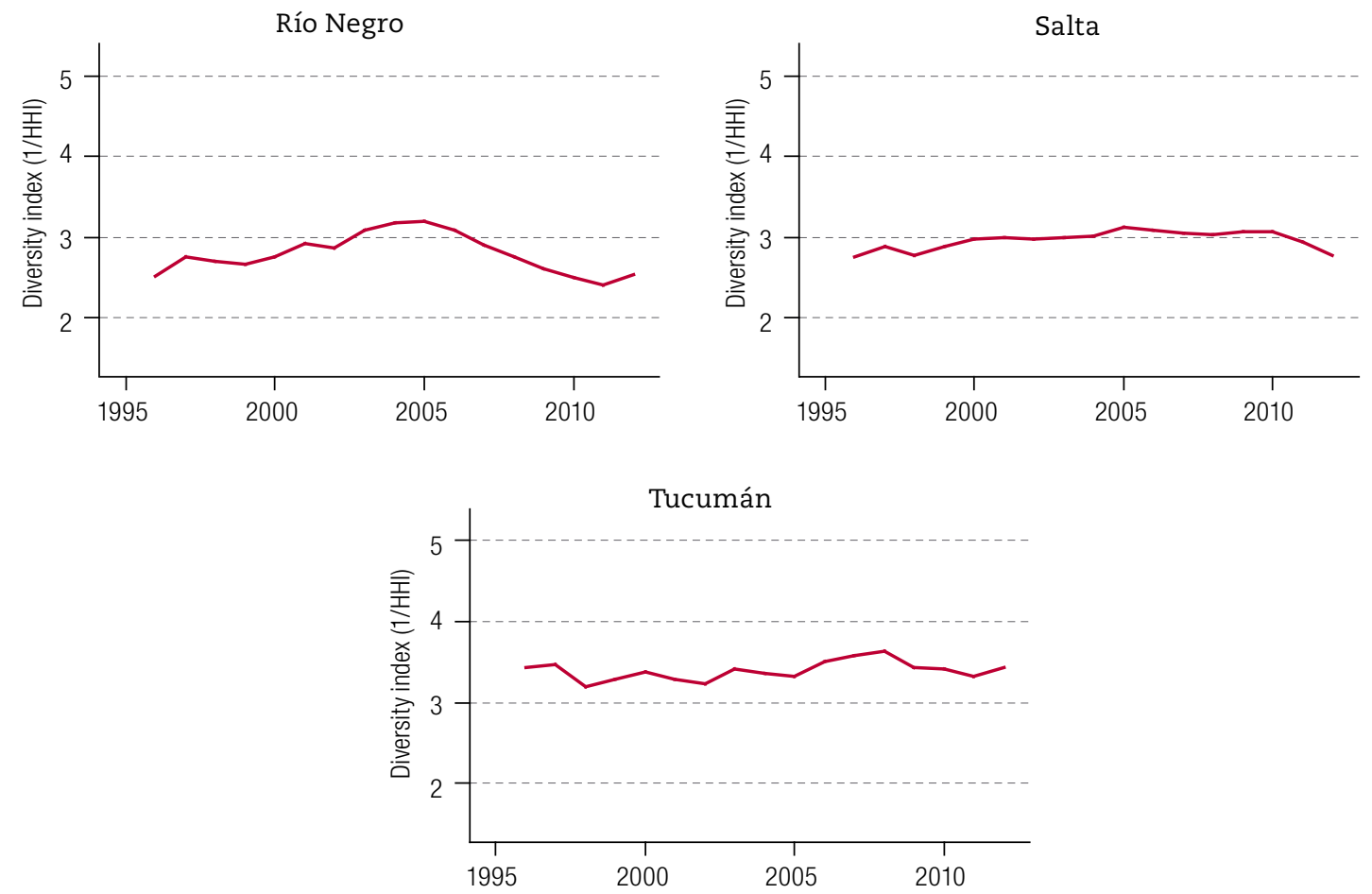

D. Oil and fishing complexes
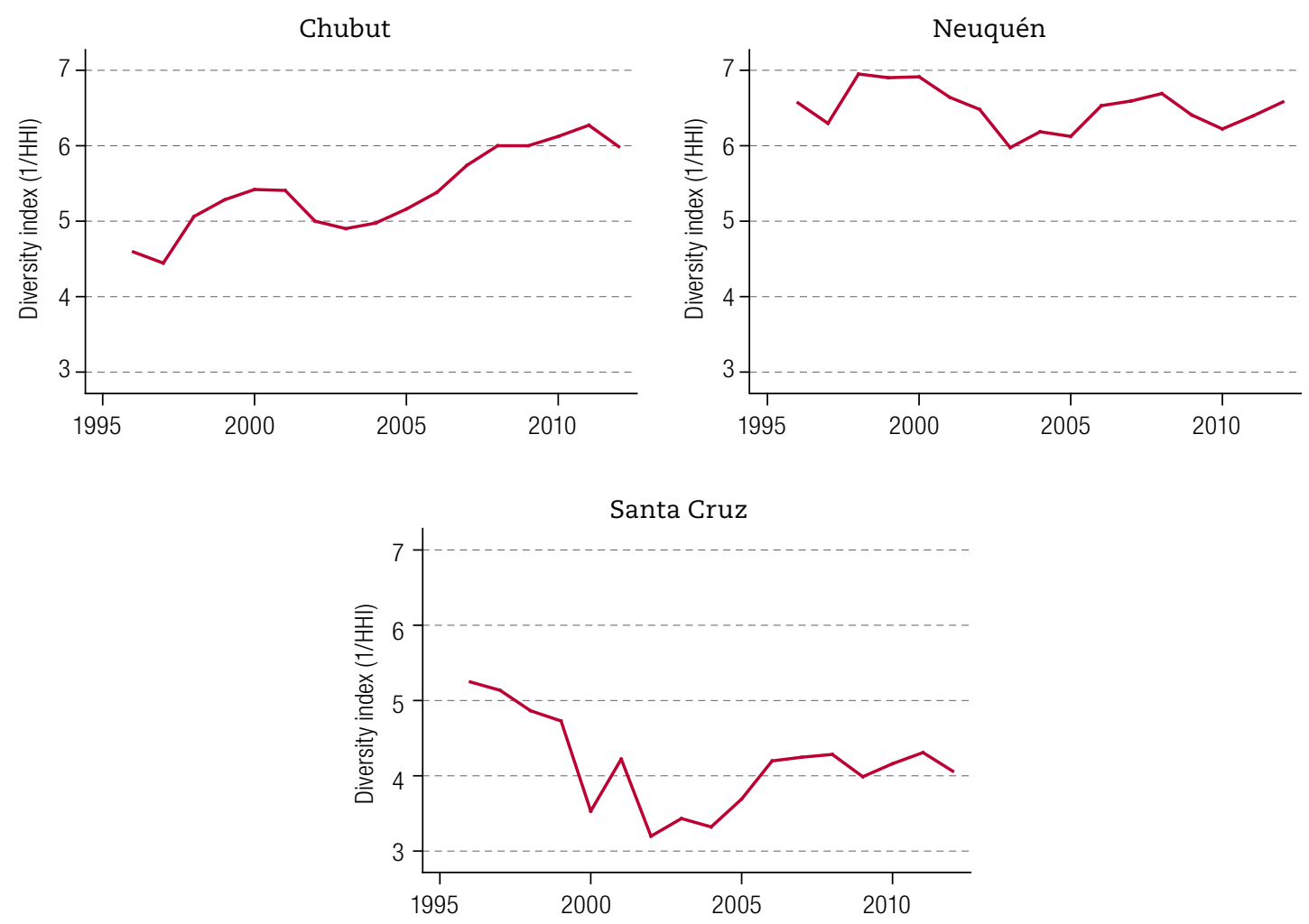
Figure A3.1 (concluded)

\section{E. Forestry and textile complexes}
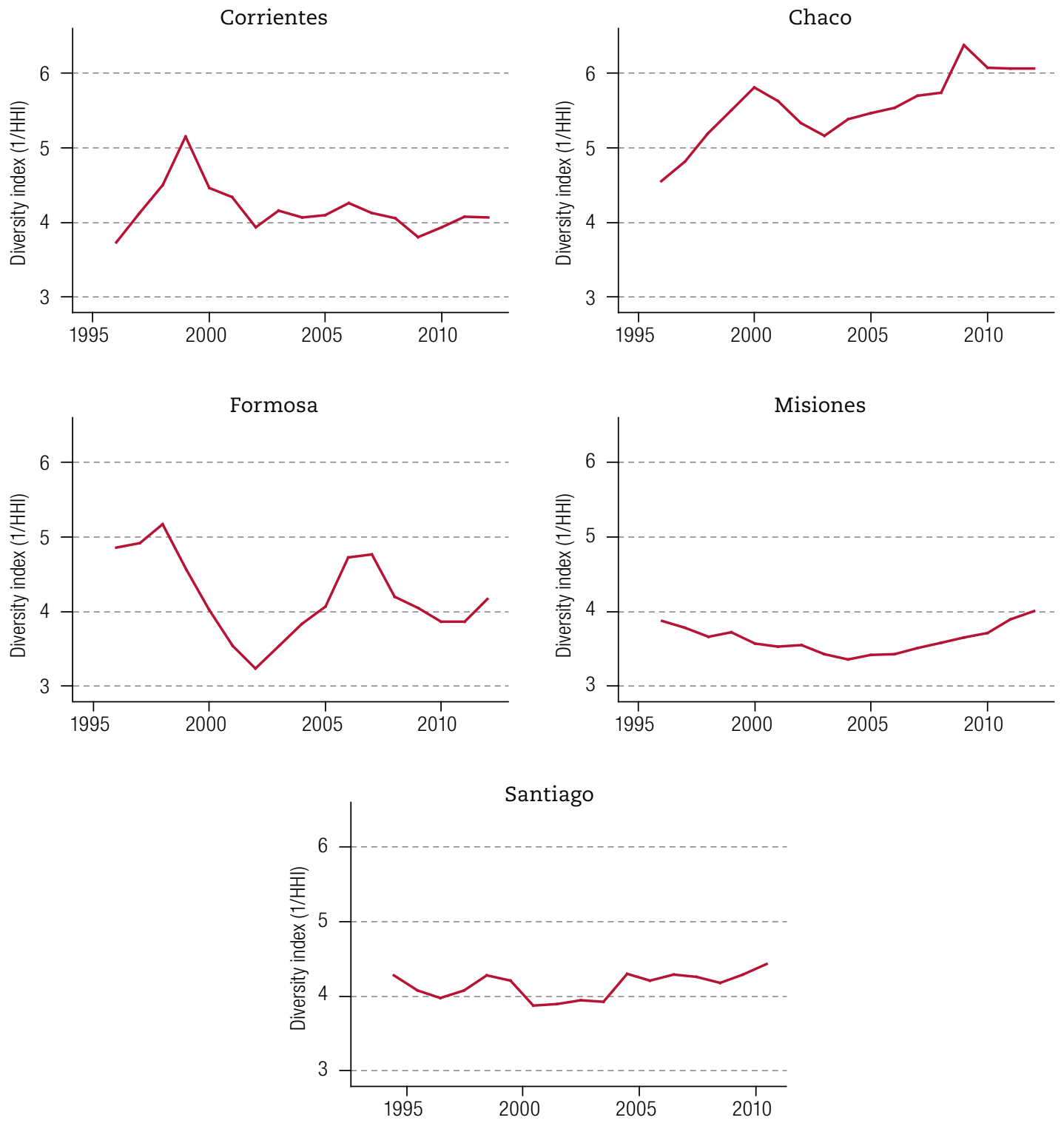

Source: Prepared by the authors, on the basis of the Dynamic Employment Analysis Database (BADE). 